\title{
Yttria-Ceria Stabilized Tetragonal Zirconia Polycrystals: Sintering, Grain Growth and Grain Boundary Segregation
}

\author{
M. M. R. Boutz, A. J. A. Winnubst* \& A. J. Burggraal

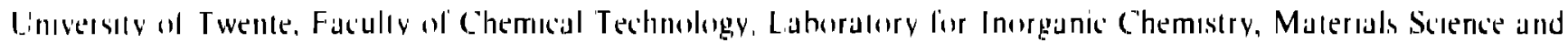 \\ Calalvsis, P(), Bus 217,740) AE Enschede, The Nelherlands
}

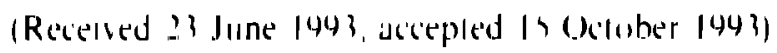

\begin{abstract}

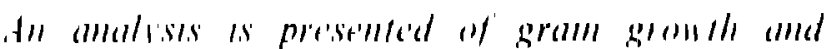

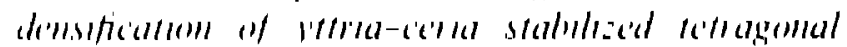

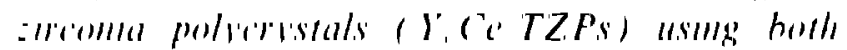

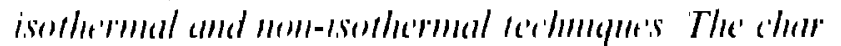

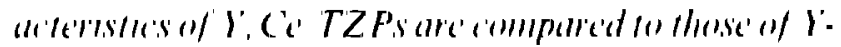

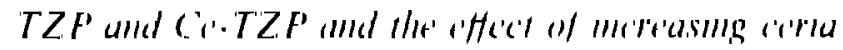

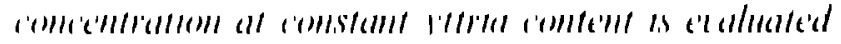

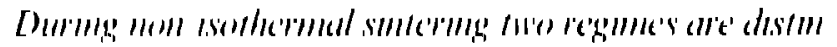

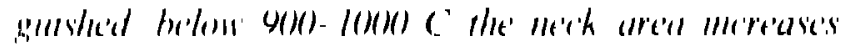

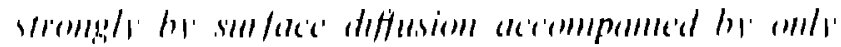

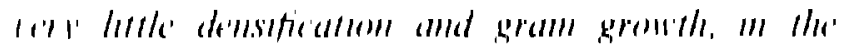

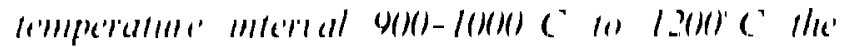

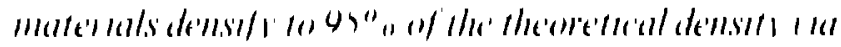

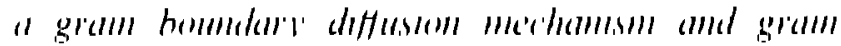

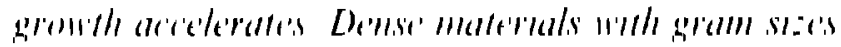

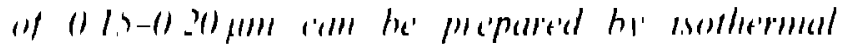

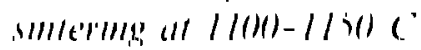

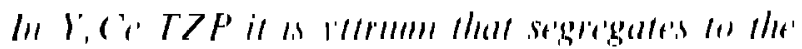

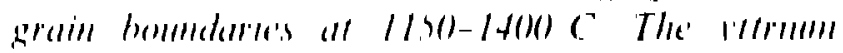

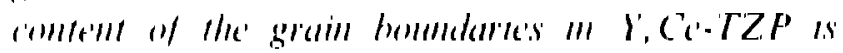

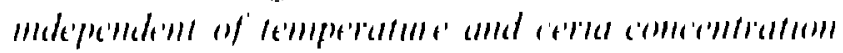

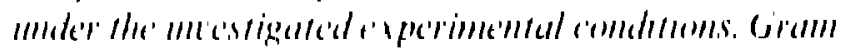

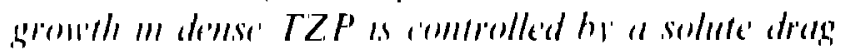

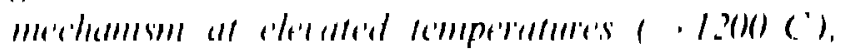

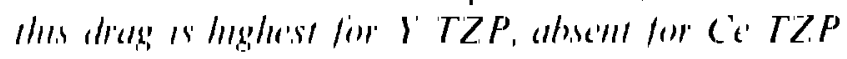

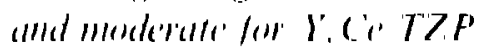

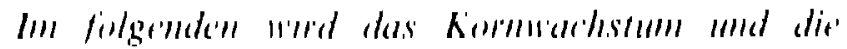

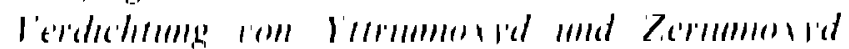

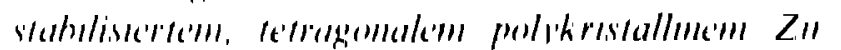

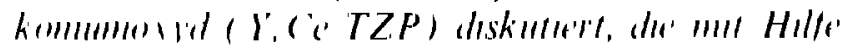

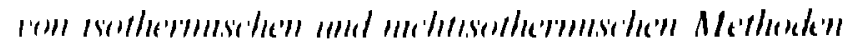

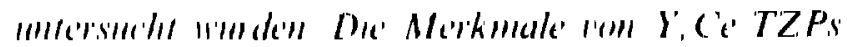

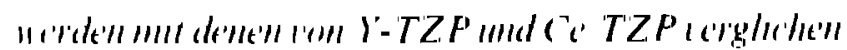

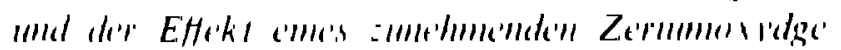

" To whom anrcespondenore "hould he addrewsed

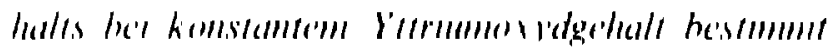

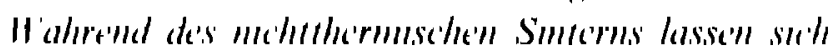

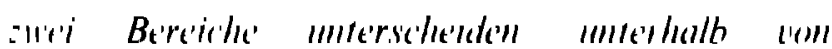

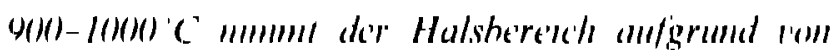

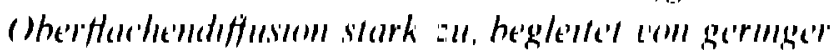

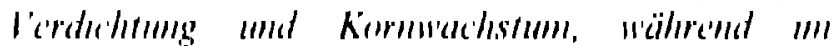

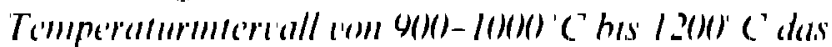

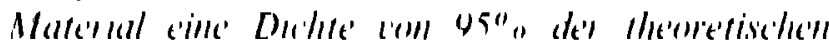

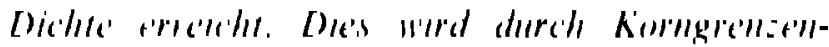

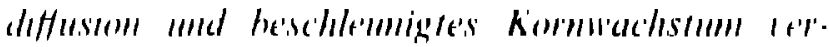

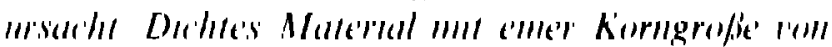

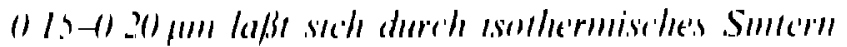

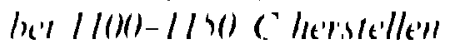

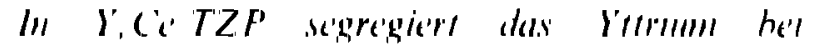

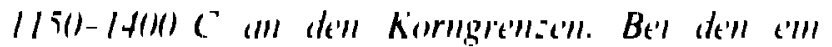

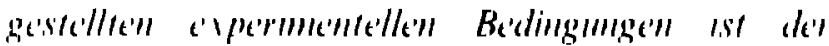

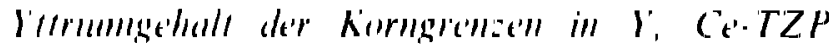

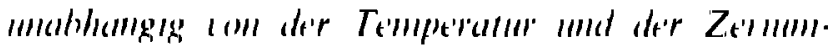

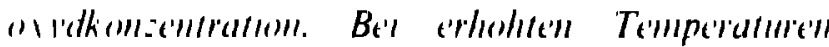

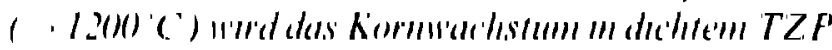

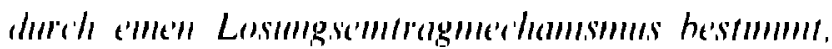

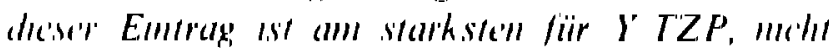

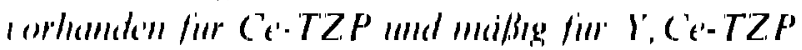

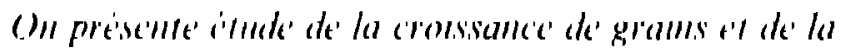

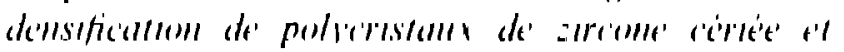

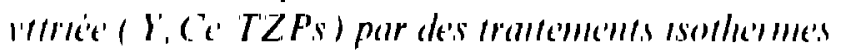

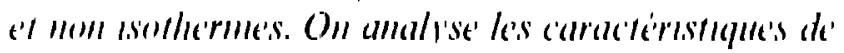

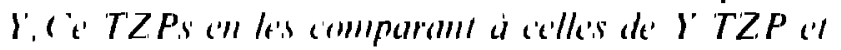

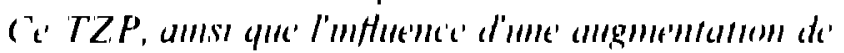

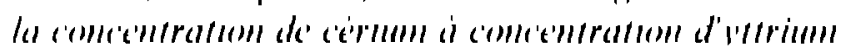

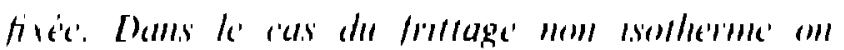

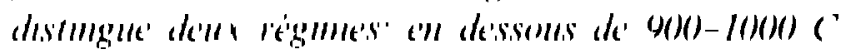

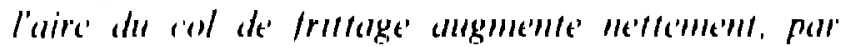

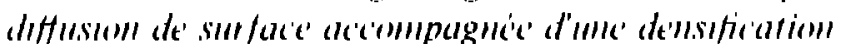

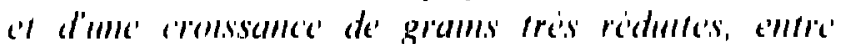

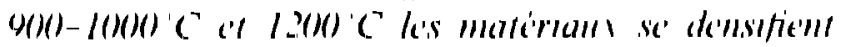
S')

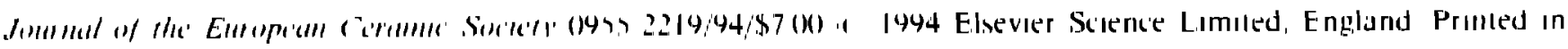
Gireal Britan 
foints de' grains, tandis que' la cronssance de's grains est

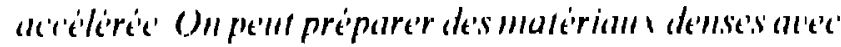

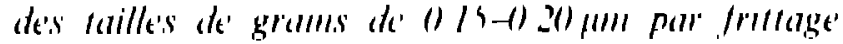
isorlle'rme' a $1110(1)-11.50)^{\prime} \mathrm{C}^{\circ}$

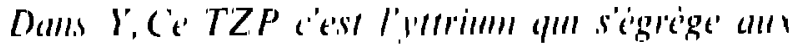

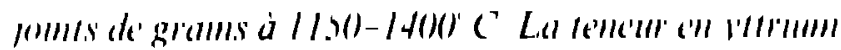

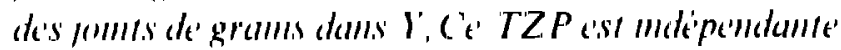

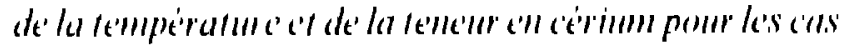

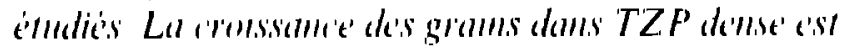

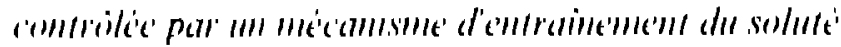

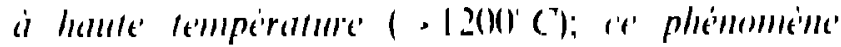

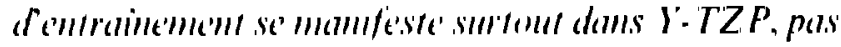

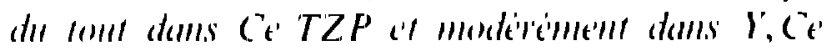
$T Z P$.

\section{Introduction}

Polycrystalline telragonal zirconta cerames repre. sent a class of structural ceramics possessing high strength and toughness ' Therr excellent mechanical propertles are derived from the stress-induced inartensitic transformation of the metustable tetragonal to the monocinic phase. "In order to relain the telragonal phase at room temperature the graln size must be kept below a critcal value. This value depends, among other lactors, on the concentration and lype of oxide (e.g, $\mathrm{Y}_{2}\left(\mathrm{O}_{1}, \mathrm{CeO}\right)_{2}, \mathrm{Mg}(\mathrm{O}), \mathrm{CuO}$, ete) used to stabilize the tetragonal phase, bul is typically less than $1-3 / 1 \mathrm{~m}$. The most intensively studied systems are $\mathrm{ZrO}{ }_{2}-\mathrm{Y}_{2} \mathrm{O}_{1}$ and $\left.\mathrm{ZrO}\right)_{2}-\mathrm{CeO}_{2}$

Y'trola doped lelragonal zurconta polycrystals ( $Y$ TZPs) possess a maxımum bending st rength equal to 15()) MPa at approximately $3 \mathrm{~mol} / \% \quad \mathrm{Y}_{2} \mathrm{O}_{3},(3 \mathrm{Y}$ TZP) and a ma xim um in l'racture loughness equal (1)

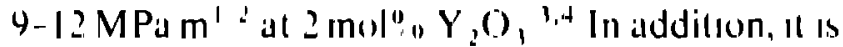
well documented that grain growth in Y'TZP ceramic's is extremely sluggish both under static and dynamic conditions." -4 Near theoretical densities with gram sizes in the submicron range can now routunely be obluined using commerclally avaulable powders Fine-graned (1) $3 / 1 \mathrm{~m})$ 3Y-TZP was lhe firsl 'eramic material showing true superplastic behaviour, as demonstrated by Wakal 't $^{\prime} a^{11}$ in lash However, the maln deficiency of Y T'ZP materials is the poor stability of the tetragonal phase In humid atmospheres at $1(1)(1)-4(0))^{\prime \prime} \mathrm{C}^{11.12}$

Ceria-doped letragonal zirconla polycrystal (CeTZP) materlals, on the other hand, display a considerahly improved slability ol the tetragonal phase " and possess a higher fracture loughness 1.14 compared lo Y-TZZP However, graln sizes in Ce 'TZP are generally in excess of I $\mu \mathrm{m}$ after free sintering' due to its high grain boundary mobilily, making " a prom less attractive for hot forging processes Indeed, no superplastic elongations have been obtanned so far with ('e.T'ZP, due to strain hardening caused by extensive dynamic grain growth. " Finally, the bending strength of Ce-T'ZP is generally lower than that of Y-TZP materials 1,14

It is therefore anticipaled that using both yttria and ceria as slabilizers for telragonal zirconia will lead to a material with low grain boundary mobility, improved chemical stability and good mechanicul properties. The improved stability of ytlria-ceria sluhilized tetragonal zirconta polycrystals (Y, C'eTZPS) has indeed been reported hy several authors ${ }^{7-14}$ and is investlgated in more detall elsewhere "Lamited work has heen done so far on mechamical properties of Y,Ce-TZP, but the results seem promsising. Hirano \& Inada" reported a strenglh of $1(0) 0$ MPa for $2.5 \mathrm{Y}, 4 C^{\prime} \mathrm{e}$ 'TZP, while a loughness equal to 8 MPa $\mathrm{m}^{12}$ is reported by the present authors elsewhere" for a similar compo sition Prelimiliary work perlormed in this group ${ }^{4}$ confiumed that $Y, C C^{-}-T Z P$ has a much lower gram boundary mobilıy than Ce TZP, especially at high temperaltures (1400)

In this paper an analysis is presented of grann growth and densificullon of $\mathrm{Y}, \mathrm{Ce}$.TZP using both isothernal and non isothermal lechniques. The characleristics of ${ }^{\circ} \mathrm{Y}, \mathrm{Ce}-\mathrm{TZP}$ are compared 10 lhose of $Y$ TZP and Ce-TZP and the effect of ancreasing ceria concentration al constant yttria concentration is evaluated. Segregation of solute cattons io the grain houndaries has been analysed and the role of the segregated layer during gran growth is dis cussed Segregation ol' solute caltons to the graln boundaries and external surfaces has been observed in pure $Y$ TZP ${ }^{\text {rn, } 2}$ and $\mathrm{Ce}$-TZP doped wilh alioval lent elements. " This segregation layer is believed 10 hinder grain growth by means of a solute drag inechanism." In pure Y-TZP ytlrium segregates strongly to the free surfiaces already at $1(1)()^{\prime \prime} \mathrm{C}^{22}$ while no segregation of cerrum to the grain boundarles has been observed in 12 Ce-TZ.P."

An efforl has been inade to produce powders with good sinterability, which allow densification al low temperalures $(110(0)-1.50(0)$ (). In this way very finegramed microstructures can be obtained, which are lavourable among other lactors, for superplastic formang, processes, hecause of their enhanced ducility:" and higher strain rates" compared to themr courser-gramed counterparts

\section{Experimenial Procedure}

\subsection{Powder synthesis}

Zirconia powders with different amounts of yttrium and cerium (see Table I) have been synthesized by a gel-precipitation technique using metal chlorides as precursor chemicals (hence the name chloridemethod" to be used herealter) The precursor 


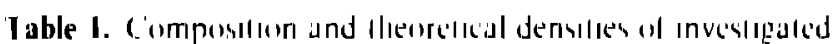
puwders

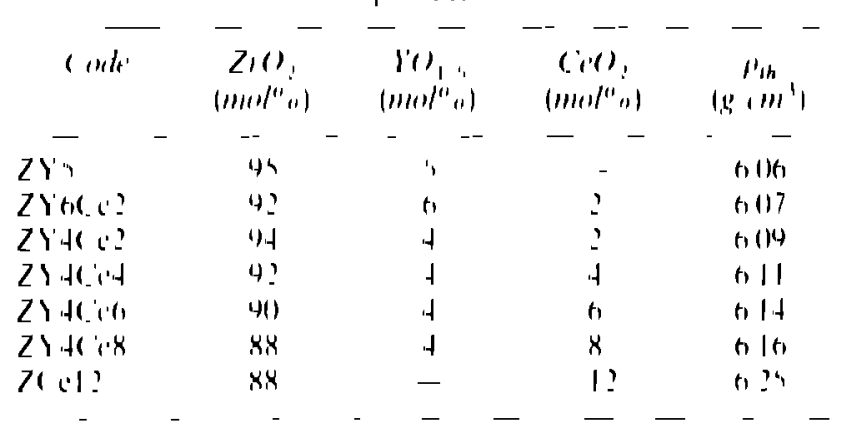

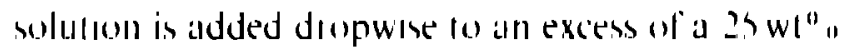
ammonia solutoon and the $\mathrm{pH}$ is mamtaned ahove II Al this high $\mathrm{pH}$ the hydroxides al zirconium, vilrum and cerrum precopitale instantaneously al hagh nucleation rates In this way the difierent components inix on an atomac sciale The obtanted gel is then thorouglily washed with water ammonla mixtures 10 remove $\mathrm{Cl}^{-}$ions. Hydrolysis and washing, procedures were carried out in a balfled reactor vessel eyuipped with a dispersion or high energy disc turbine manulactured following the design ol van de Grail" it al." Alter the waterammomla wishong steps, the free walter is iemoved hy washong with ethanol The replacement al' waler by ethanoll lowers the capollary forces actong on the gel durmg drying signiticantly Furthermote. elloxy groups allach lo the surfice of the hydoroxide partcles and prevent to a large extent the formidton ol' strong interparticle honds durmg calcinatom?"

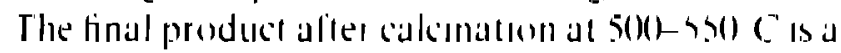
manocrystallme powder (crystallote slzes $x-10$ nom) will a low degree ol agghomeraton More experi meiltal detuils concerming the synthesis method and powder properles can be found in Rel' is 'This winlhesis method hals beenl reported hiss by Haherlan III 1479." Van de Giaal' a' al "th destgned al halffed ressel reactor especially sillahle for thas innthess mellind

\subsection{Green compact formation and sintering}

Gilcen compacts were prepared by cold isostalc pressing of the synthesized powders, tirst at 1(1)-2(1) MPa and finally all $4(0)$ MPa. Samples used for fraln size analysis were healed durme monasolhemal runs with 2 Cimon in a Vectslar lube furnalce (In alrt lo a lemperallure on the range 70) $14(0)($, ammediately followed hy coolma down lsolhermal experiments were conducted at

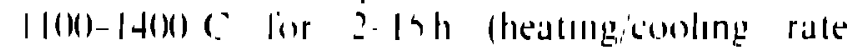
2: min). Disc shaped specomens (helght b-l(1) nn dlameler l(1-15mm) were used durng non isotherinal experments with inaximum tempera lures of $70010-11$ ho $C^{\circ}$ All wher experiments were perlinmed with cylindricul specimens (height II- (x minn. diumeter $x-4 \mathrm{~mm})$
Free sintering behaviour has been analysed in detal by meilns of dilatometry using a Netzsch 4)2 E dilatometer Densites were calculated from the green density and the observed linear shrinkage of the specimens, corrected for thermal expansion and weight loss (dire to removal of absorbed water) ol the specimons. using:

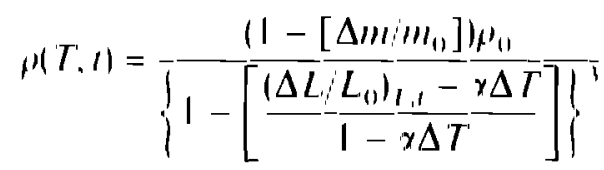

whe're $\mu_{11}$ is the green density, $\Delta m i m_{1}$ the relutive welght loss, $\left(\Delta L / L_{0}\right)_{T, t}$ the relallove shronkage at a given temperalure $T$ and lame 1 . ' the thermal expansion coeflicient and $\Delta T$ llie temperature difference (with respect (1) room temperature) Good agreement wals found between tinal densitles cal culaled in thas way with those measured by Archumedes' lechmopue. Courng non isothermal experiments samples were heded with $2 \mathrm{C} / \mathrm{mm}$ lo $1450(\mathrm{C}$, whole sothermal experiments were perfor med al II(1)- I I 40 C linr $15 \mathrm{~h}$ (heatong rate $2 \mathrm{C} / \mathrm{min}$. cooling rate $5(\mathrm{C}$ 'mon)

\subsection{Characterization of the porous texture}

Nillogen adsorptonndesorption isolherms were whiained at $77 \mathrm{~K}$ usme a Mcromernles ASAP 24(0) system Specitic surliace areas were analvsed by the BET melhod The I plot method "l has been used to inspect il mocroporosily (pores having widths less thall 2 minl wals present. Me'sopore size distrihutoms were calculaled following the method developed by Barell a' al (the B.JH method) assumng a cylundracial purte model" Bulk densilses were meilsured bv Archumedes' lechmoque (In $H_{g}$ ) Relathve densiltes nere calculated on the hasss of the theoretical densities as listed in Table I

\subsection{Grain size determinalion}

Gram slzes 1 . $1001 \mathrm{~nm}$ ) were determuned by $\mathrm{X}$ raly line broidening measurements using, a Philips PW 1370 difiractometer with CuK, radiation For this purpose the specomens were giround after sontermg. and annealed at $6(x)(C$ lor 30 mon in an altempt 11 remowe residual stresse's duce to grondmg Step scans were laken over the range of $2(\Leftrightarrow)$ from 26 lo 33 in

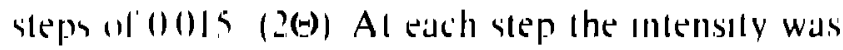
measured durmg len secolnds. The specomen was rotaled around the vertlcal axis lo luarther amprove counting stalistces

The difractunn peaks appear on the measured 2 (G) ange: the $(11$ I) reflectoon ol the tetragonal phase and the $(-111)$ and $(111)$ reflectouns of the monoclinic phalse. The lanewidths observed in thas investggation caused all overlap of the (wo monoclinic reflectoons with the (1II) reflection of the tetragonal phase, resultong in a poor resolution of the peaks even for 
the sumples heuted to the highest temperature A pattern-filting technique based on the model devel. oped by Schremer \& Jenk ins " was therefore used to resolve the overlapping peaks 'The grain size $[$ ' was calculalted from the paltern resolved (III) peak of the tetragonal phase using the Scherrer equation.

$$
[)_{1111)_{1}}=\frac{(1.94 \%}{\beta_{1,2} \cos \theta}
$$

$\beta_{1:}$, being the width of the peak at hall inaximum intensity correcled lor the $K^{\prime} x_{1} / K^{\prime} a_{2}$, douhlet and instrumental hroadening, , the wavelenglh of the radiation used $\left(\mathrm{Cu} K^{\prime}\right)$ and $\Theta$ the Bragg angle

Gruin sizess $100(\mathrm{~nm}$ were determined by the lineal intercept technique from SEM micrographs (Hilachi SX(0) or Jeol JSM 3.5CF) of polshed, thermally elched cuts using $D=156 L$, where $L$ is the alverige lineal intercept."

\subsection{X-Ray pholoelectron spectroscopy (XPS)}

The chemical composition of the grann boundarles has been analysed by means of XPS on intergranular fracture surlaces Fracturmg necessarily look place outside the UHV system "I the XPS equipment Measurements were perlirmed using a Kralos XSAM $8(0)$ apparatus Both $\mathrm{Mg} K$, and $\mathrm{Al} \kappa_{*}$ radaloon have heen used (1) generale pholoelectrons. The Zr $3 d, Y$ Y $3 d, C e$ C $3 d$ and $S$ I $2 p$ line's have been used lorr quantificulaon. Tocorrect lor charging $\left(+3-5\right.$ eV) the hinding energy of the $\mathrm{Zr} 3 d_{1}$, , line has been fixed at 182.2 eV. Morre experimental detals can be found elsewhere 't.:?

\section{Resulis}

\subsection{Non-isothermal experiments}

3.1.I Nom isothermal grann gronth and dinsification Graın sizes during non-isothermal sintering up to 1150 ( C are shown in Fig. 1 as a funclon of temperalture for three different Y,Ce.TZPs The gramn size evolution durmg non isothermal sontering of pute Z TZZP (composillon ZYS 8 ) hals been analysed by Theunisien at al ${ }^{4}$ and is also shown in Fig. I lor reasons al comparison. All powders have an intlal crystillate size of $8-4 \mathrm{~nm}$ (surluce ateds ranged Irom $\left.4510125 \mathrm{~m}^{2} / \mathrm{g}\right)$. The shape ol the curves strongly suggest that Iwo grain growth regimes can he disungurshed Up lo lo(k) ' $\mathrm{C}$ the grain size increases only very slowly (1) 2()$-3(0 \mathrm{~nm}$, while above this temperalure gran growth clearly accelerates.

The increase of densily with temperalure is shown in Fig. 2. Up to I000' $\mathrm{C}$ the densilies are very similar, ahove this temperature densification of $Z Y Y$ is somewhat laster II can be seen that above 1000$)^{\circ} \mathrm{C}$. where grain growth accelerates, relative densittes of only ho\% are observed. Upon healıng from $10(0) 0$ to

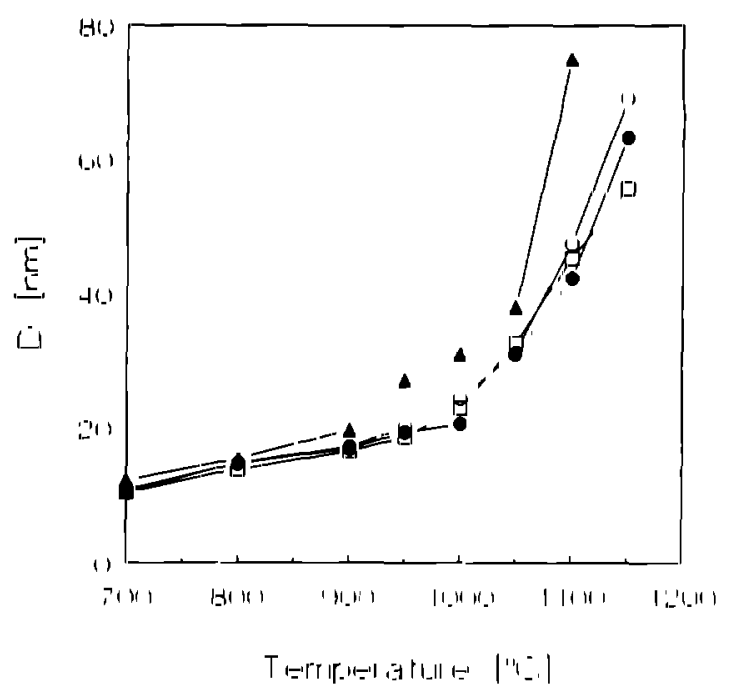

Fig. I. Cirdin wzes, whlanned by XRLB as a luncion al lemperalurc during hesling, with ? 'C:nill [ala lor ZY \& 8 firom

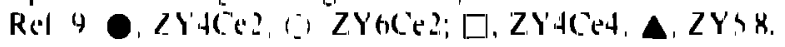

1200) $C$ the density lurther increases to 9.5\% for all compositions 'The densificaloun behaviour is analy sed in more detail in Sectlons 313 and 3.2.1

Additional graın growth dala during healıng up (1) $14(0) C$ are shown on Fig 3 lour $Z Y 5$ and $Z Y 4 C e$ ? Above 1200 ' $C$ the materlals have essentially reached their final density (porosity is below 5\%). It can be seen from Figes 1-3 that up $1011501 \mathrm{C}$ both densticalion and graun growth are somewhat fister in Y.TZZP than in Y,Ce-TZP. Ahove $115(1)-12(0)(C$ grain growith in pure $Y$ TZP is slower than in Y',Ce TZP 'These findings are lurther supporled by isothermal experiments as described in Section 32.2

Gian growth kinetics are normally analysed under isothermal conditions by measuring the grain size as a function of time, in acoordance with classical grain growth theories as developed, amongst others, by Brook" for non-densilying

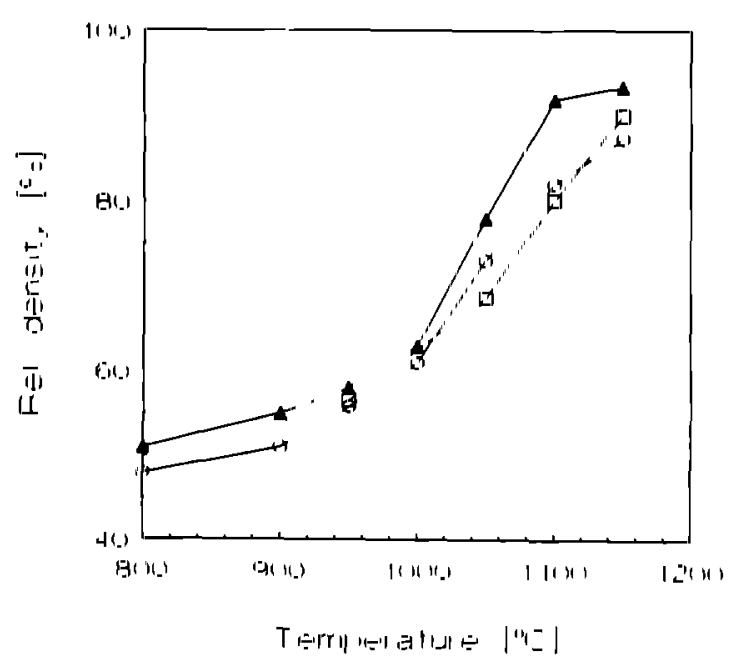

Fig. 2. Relalive densily do a liuncillon oll temperalure during heding wilh 2"Cimon Grian sizes in Fig. I. A. ZY' ZYho'e. I, ZY' YCe4 


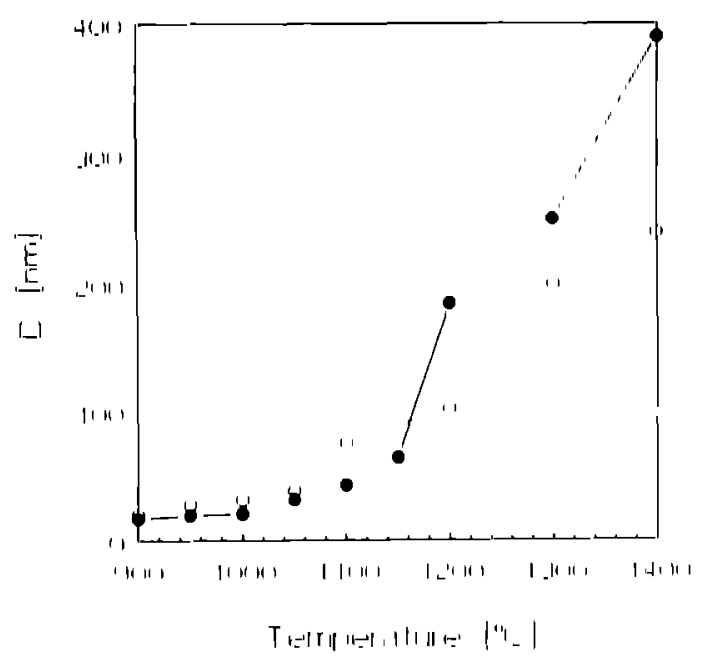

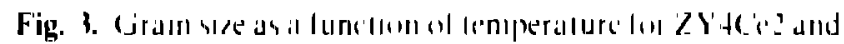

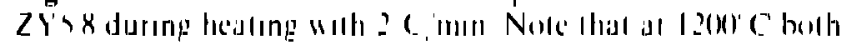

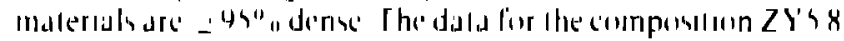

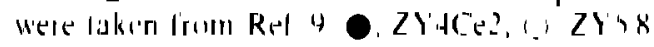

systems. The general grann growlh equation for isothermal conditions is"

$$
[]^{n}-[)_{11}^{n}=k 1
$$

where $\left[\right.$ ) in (he inslantuneous graln size, $D_{0}$, the inilial grain saze in a particular grann growth regime, 1 lıme, $k$ a kmelic constant and $n$ is the su-culled gram growth exponenl The gralln growth exponent can have al value hetween I and 4 depending on the ralelanitung step durıng graun boundars migraluon." Activalun energles can he wblaned from an Arrhemus plot with giriol growilh dalta recorded at a Inımmum of three temperatures. Il can be shown (see the Appendix), that in the case of heallong with a conslant ale $/ \beta$ the general graln growth equatoon ladnsliurms lo

$$
\left.[)^{\prime \prime}-I\right)_{11}^{\prime \prime}=\frac{K_{1} R T}{\beta\left(\frac{\partial}{2}\right.} \exp \left(-\frac{()}{R T}\right)
$$

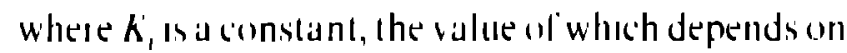
the rale limilung step durmg glatn growth, $Q$ is the apparent aclivaton energy and $R T$ has its usual meanıng Although equs (3) and (4) alte strictly speaking only valud for non densilyong systems, it has been findud by the present authors as well as hy "thers" th that even in highly porous systems gian growlh can be adequalely described by these equations It is clear, however. that the apparent actovation energy cannol be altributed (1) graln boundary migralion only, hut must certalnly he influenced by the densiticalom process

Equallan (4) can be rearranged (1)'

$$
\ln \left(L^{n}-[)_{1}^{n}\right)-\ln (T)=\ln \left(\frac{K_{1} R}{\beta C} \frac{Q}{\zeta}\right)-\frac{(!}{R T}
$$

By plotting the left hand side of eqn (5) versus (1/T) a stralght line should be ohtulned, the slope being. equal to $(-Q / R)$. L. Intear regression by the least squares method using eqn (5) has heen performed to determine which $/$ value provides the hest fit The value of the apparent activation energy is calculated from the slope of the best-fit curve.

At temperatures below $10(10)(\mathrm{C}$ the best fit is whianed for a 11 value of 3 to 4 the dafference in correlatoul colficient hemg lon small lo allow lurther discrimanatoon the corresponding actov. alcon energeses are rather low and are typoully equal (1) $9(1) \pm \mid 6 \mathrm{~kJ}$ mol $(11=3)$ and $\mid 3(1) \pm 3+\mathrm{kJ} / \mathrm{mol}$

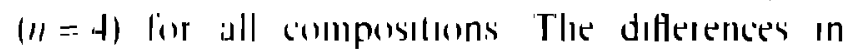
correlation coefficients of "lle different 11 values are rather small in the lemperature range $1(x)(1)-1150)($, hut the dalla are hest represented hy $\|=2-3$ The apparent aclivallon energles are lypically $245 \pm 67 \mathrm{~kJ} / \mathrm{mol}(11=2)$ and $375 \pm 80 \mathrm{~kJ} / \mathrm{mol}(11=31$ fin the insestgialed Y'Ce-TZPs

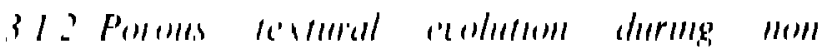

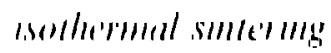

Il hals already heen shown lhat densification and grilln growwth of the different Y,Ce-TZPs is quite

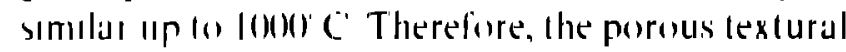

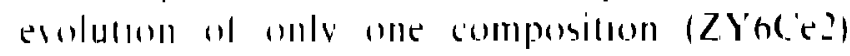
liits heen sluded. In 1 le 4 the mitrogen adsouptoun desorptorn isotherms ol a green com

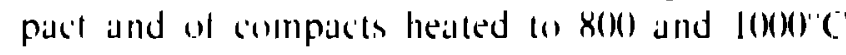
respecilvely are shown. All llse isolherms are ol type IV according lo the BDDT (Brunaue, Demmg, Demmong and Teller) (dassificallon," which is chalactersske of mesoponoms systems The shape ol the hystereses gradually changes liom type E Io type A. following the classificution ol de Boer it Thas andicates is thal the pore shape changes from tubulal capillaries with wide parts of vartous widths in the

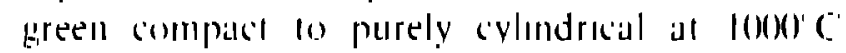
Figure s shows a $t$ plot of the green compact, where the adsoribed volume (STP) is plolled versus the stallstical thickness of the idsurhed inulalaver This I plot has been constructed from the adsorption isolherm ol the green conmpace geve'n in Fig, 4 using

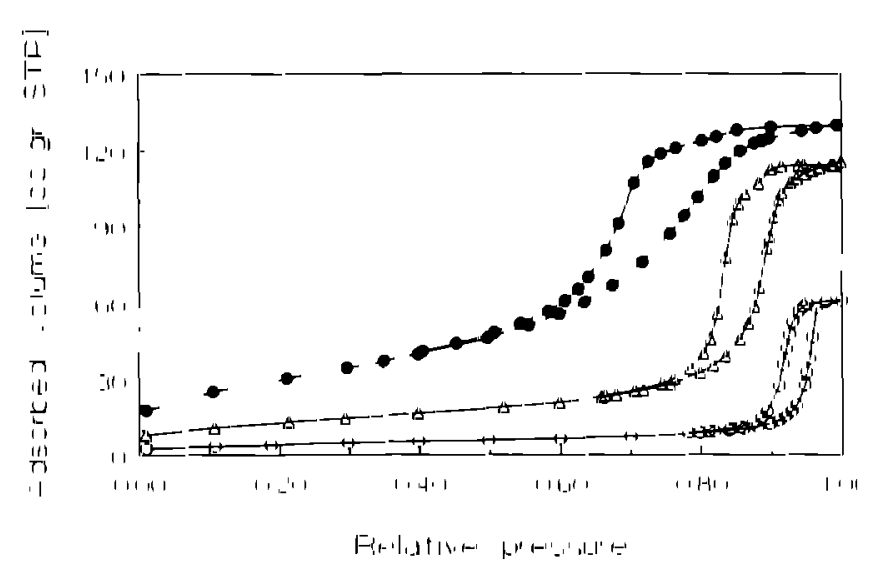

Fig. 4. N: surploun iscuherms of ZY'te.'e? compacts, in the

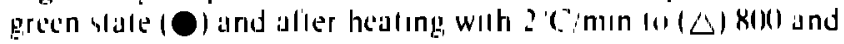
$(1.1) 10(0)($ c 


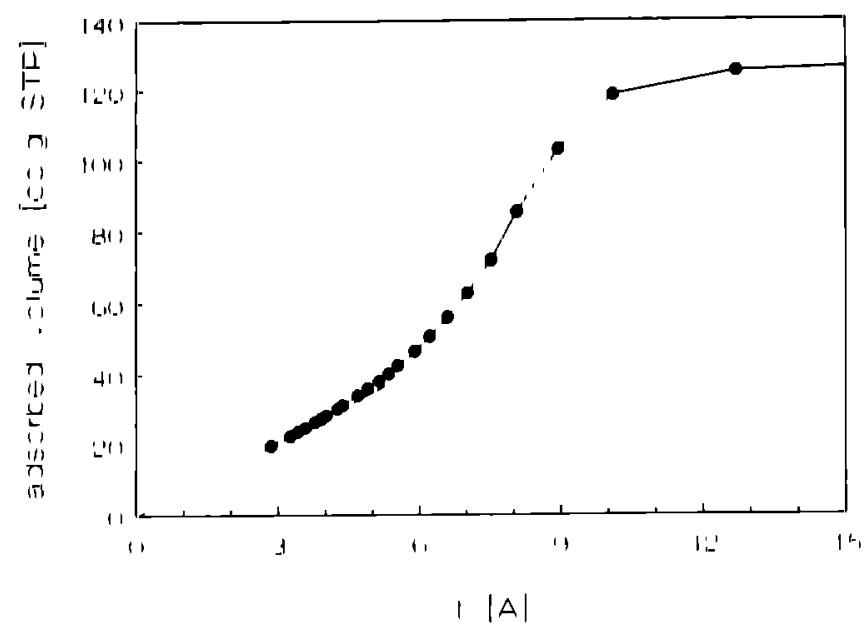

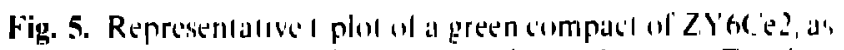

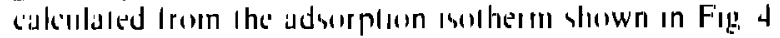

the appropriate standard isotherm of a non-porous solld given by Lecloux \& Pirard. ${ }^{14}$ The standard isotherm is selected takmg into account the C value $1=107$ in the case of ZYGCes in the green stale) and consequently the adsorbate-adsorbent interacton. The shape of the t-plot of Fig 9 is representative of a mesoporous soldd showing filling of pores due lo capollary condensalon. The linear branch of the t-plot goes through zero. demonstrating the absence of moroporosity The surfice aleil (S) calculated lirom the slope of the linear branch of the t-ploc "1 is identical to the BE'T' surfice ared. No incroponosity corrections al the $S_{\mathrm{HE}}$ values are therelore necessary. Figure $h$ shows the pore size distributions (PSDs) as calculated from the ad sorptoun branch-lor a green compact and aller heating $108(0)-400)(C$. It is clear that the PSD is hecoming sharper and the pores are coarsenung. during, sintering; the most lirequently observed pore radius increases from $44 \mathrm{~nm}$ in the green compact lo $13.5 \mathrm{~nm}$ alter healung 10900$)^{\prime} \mathrm{C}$ Pore sizes calculated from the adsorptoun branch of the hysteresis are representalive ol the 'wide bodies' of the pures, while pore sizes calculated from the desorption hranch

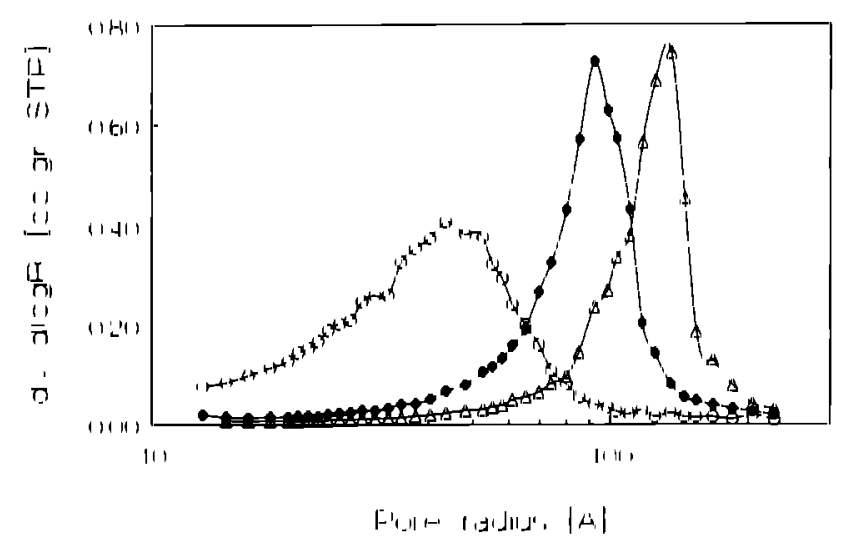

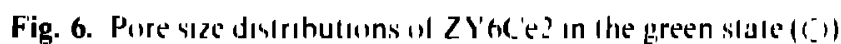

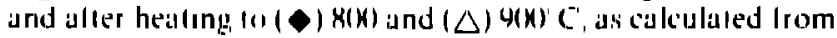
the adsorploon branch of $N_{4}$ sorplan isolherms represent the pores' entrances. PSDs calculated from the desorption branch are generally sharper and are witen ured in ceramic technology, but the "wide hodies' determıne the sinterability of a malerial

Normally, grain growth is considered lo occur only in the last stage of sintering, where porosily is less ihan $10 \%$. This investigation as well as those of "shers ${ }^{3 t, 411}$ has shown that graln growth occurs at high values of porosity In the low temperature (LT) regime, I.e. below I000' $\mathrm{C}$, the porosity is decreasing. lrom 5.": in the green compact (1) $35-40^{\circ}$ '" al Iocos" "To have a helter understanding of graln growth in such porous malerials, one would like to know how the amount ol neck area (and thus the amount of solid-solid interlace) increases with temperature. For this purpose the fraction of the geonnetrical surface area $\left(S_{G E 0}\right)$, which is not accessible (1) nitrogen $\left\{\left(S_{\mathrm{GEO}}-S_{\mathrm{BET}}\right) / S_{\mathrm{GEE}}\right\}$ is calculated The geometrical surlace areal can be culculated from the crystallite sizes determined from XRLB assumng (1) the crystallates have spherical morphology and (II) no closed porosity is present +1 With these assumptions $\left\{\left(S_{G, F(1)}-S_{\mathrm{HEF}}\right) / S_{\mathrm{GEO}}\right\}$ is identical with the tolul (fractional) neck area per gla all $S_{\text {NEI }} S_{\text {JEII }}$ The neck areal hals been found 10 increase with temperalture from $300^{0}$ is at 800$)^{C} \mathrm{C} 10$ $4(1)^{\prime \prime}$ ant 110()$^{\prime \prime} C^{\prime}$ At that stige the density equals 80-85\%" in Y, Ce-TZZ.P and some closed porosity is present. The fractomal neck area is therelore in

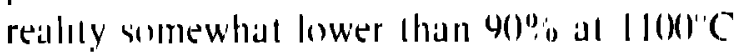

To identily the relative importance of neck growth and densification during sintering., $\left\{\left(S_{\mathrm{GEO}}-\right.\right.$

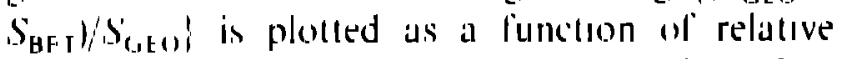
densily an Fig. 7. The varabion of the specitic surface area alone with densily is also shown in this diagram. Clearly, lwo regimes can agian he distinguished a steep increalse of the neck area wilh only very little densification followed by a strong increase of relallive density acoompanted hy further moderate

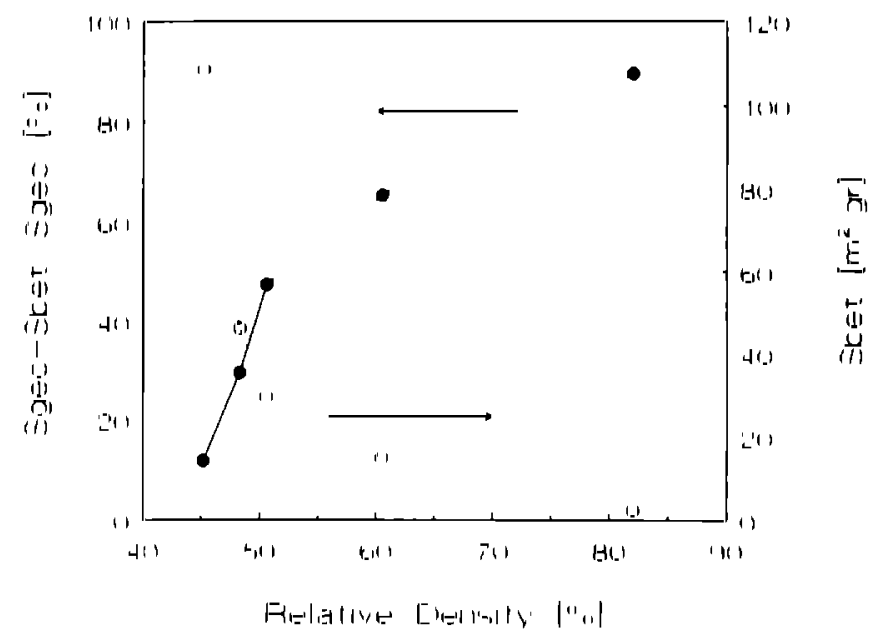

Fig. 7. The friscloon al the geomelrcal surlace isrea nol accessihle $110 \mathrm{~N},(\mathrm{O})$, respeclively the BE:T surlace area $\left.\left(c_{0}\right)\right)$ versus relallve densily. 
neck growth. The transition temperalure is stluated belween $9(0)$ and $1(0)(0) " C$ This diagram is considered to be strong evidence that surface diffusion is the domınunt mass transport below $40(1)-1000()$ an these nunustructured materials

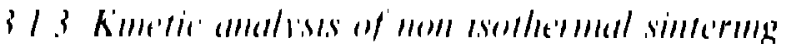
In the e emalnong part of the analysis presented here allentlon will be focused on the compositan seres ZY 4 cer will $1=2-8$ mol" ". in order lo evaluate the effect of incieasing cella concentrallonl all conslunt viltal content The sontelmg kmetcis of the end members of thos composition serses $(1=2$ and $x)$ have heell allalysed an the bass of molial stage unlermg. mudels

The general equatun lon isolhermal mallal slage sintering is t?

$$
\underset{d}{d}\left(\Delta L L_{0}\right)=K_{01} \exp \left(-\frac{\varrho}{R T}\right)\left(\Delta L L_{01}\right)^{\prime \prime \prime}
$$

where $\Delta L . L_{0}$ is relative shronkage, $I$ is linie. $k_{0}$ a mumercal constant, $m$ the sintermg exponent and the other symbols have therr usual mearing Values of $K_{11}^{\prime}$ and $1 "$ have heen labulaled for difierent sunterme mechamisms and geometries." for a lworiplete geomelis $m=1$ in the cilse ol volume diflusson and $m=2$ III the case of glam boundary dillustoll

Young \& C.utle t' have shown that in the calse ol heatlll! with a colnstant rate equ (b) call he reformulated into an integral form as follows

$$
\left(\Delta L_{1} L_{n}\right), T=K_{1}^{\prime} \exp \left[-\frac{Q}{(m+1) R^{\prime} T}\right]
$$

where $K_{1}$ is a numercial constant and the other symbols have the salne meaning as prevoussly defined. II lollows from eqn (7) that the slope of a plol of In $\left\{\left(\Delta L_{i} L_{11}\right): T\right.$, versis (1/T) is equal to $(-\ell)(m+1) R)$. The value for the appatent activ allon energy can then be calculated assumng, a cerlain sintel me mechalnism with its characteristci'm value $t$, be dominant Alternatively, $m$ can be delermmed using esther isolhermal or non isothermal techniques as will be demonstratted now.

Integratom ol' eqn (h) leads (o)

$$
\left(\Delta L L_{11}\right)^{m+1}=K_{11} \exp \left(-\frac{Q}{R T}\right),
$$

By analysung the lame dependence of the relative shronkage under isothermal conditions one can thus determine the $m$ value. Alternatively, $m$ 'an be determined by perlorming experiments with differ ent constant healing laltes (CHR). It has been shown by Woolfere \& Bannisterth that for CHR experi ments the following ielation holds hetween the relallve shrankage al a parlicular temperalure $\left(\Delta L L_{11}\right)$, and the healing rate $\beta$.

$$
\ln \left(\Delta L_{i} L_{11}\right)_{I}=-\frac{\ln \beta}{(111+1)}+\ln K_{2}
$$

where $K$ : is a numerical constant. Equalton (4) shows that a double logarithinic plot ol relative shronkalge at al spectic temperature versus heatong

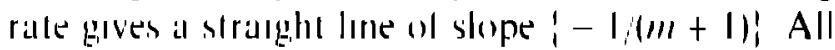
the techmiques mentooned above have heen applied 11) andyse the sontermg hehaviour of Y', Ce TZP

In Fig $8 \ln \left\{\left(\Delta L_{1} L_{(1)}\right) T\right.$, has heen plotled versus (1. T) during healong, with 2' ('min for ZY'ACe 'The Incease in relative densily with (I T) is also shown III lhos hgure The conrespondmg diagram of Z.Y HCex in very smolar 10 the one shown in Fig. $x$ For both composilouns lwo lonear palts can be recoggnzed onc at low and onte at hogh temperaltures Two palalleloconcurrell mechantsms are seen lo operale The low lempelature (L.T) mechanism is

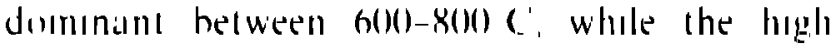
temperallure (HT) mechanism is domnant above

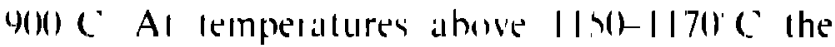
curves devale slongly from linearilv, hecause the alssumptoms anderlying equs (5)-(h) ate no longer valid all lle ohserved shrmkitge values.

Fromll an mollhermal sinterlng experiment conduc

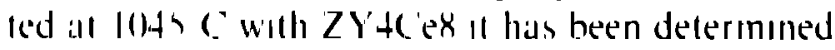
lhall $m$ equals $34 \pm 01$ Insmge eqn (7) lon relative shounkages ol' 8 - $4-15$ " "Thus shronkage inlerval is, in liate, parlls silliated on the second stige ol sontering The logh sinterithility of the mevestlgated TZPs makes 11 ginle difticult to sharactentze the first stage "1' sollering dormg isothemal experments at lemperalures ol Ioog) C"ol more, even al very high heallng ralles ('HR experiments with heating, rates of 2. 10 alld 20 (")inn have therefore also been perlormed with this composiluon and III Fig, 9

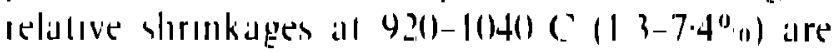

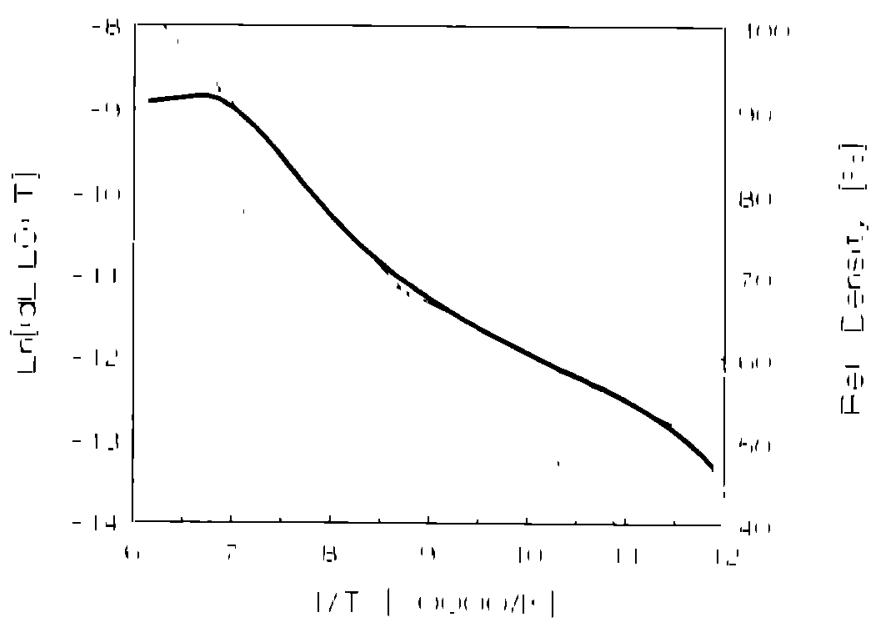

Fig. 8. The relalive densily 1. respectively the nalural

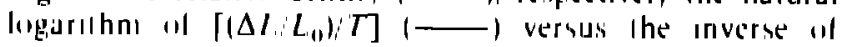

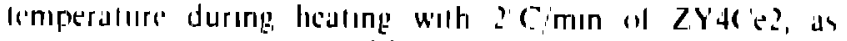
inedsured by dilalimelis 


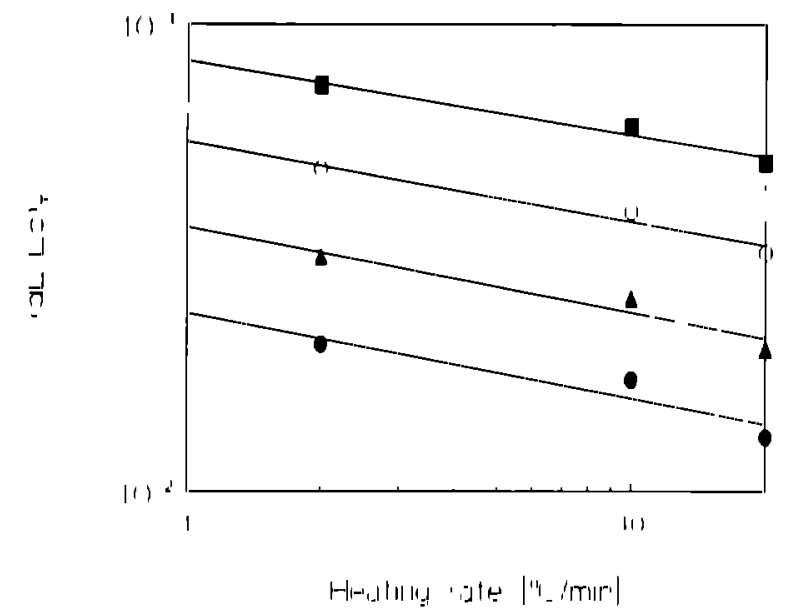

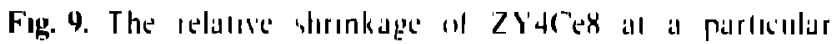
lemperalure ( $\left.\Delta L L_{0}\right)_{1}$ versus heillang, rale, as meidsured by

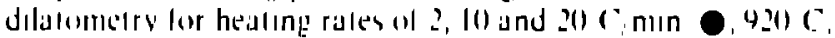

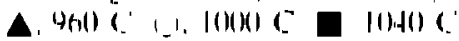

plolted versus heating rate double logarithnically. An average $m$ value of $4.7 \pm 17$ has been delem moned from the slope ol these plots using eqn (9). The $m$ value determined from the isothermal experiment $(35)$ is withon the $68^{\prime \prime}$. confidence interval of the (CHR value The $m$ values determmed here (3.4-4.7) are considerably higher than the ones predicled from grain houndary ( $m$ = 2) and volume diffusion (III = I) two-sphere models A possible explantilton lin these high in values will be given in Section 4

An m value of th hals been taken as typical for the HT sintering regame. Due lo the very small shrinkages (0) I- I I", (1) observed in the L'T regime It has been lound impossible lo determone ats challac teristc '"' value consequently, the apparent actov atlon energy for densiticallon can only he calculated liom the slope of the lonear part ol the curve shown In Fig. 8 helongmg (1) the $\mathrm{H} T$ mechanmsm 'The actovation energies (using $m=4$ ) are $\$ 40 \mathrm{~kJ} / \mathrm{mol}$ and 65S $\mathrm{kJ} / \mathrm{mol}$ lour ZY4Ce2 and $\mathrm{ZY} 4 \mathrm{Ce}$ respeclively These results ale in good agreement with the results

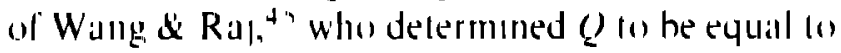
$61.5 \pm 8(1 \mathrm{~kJ} / \mathrm{mol}$ lior $2.8 \mathrm{Y}-\mathrm{T} Z \mathrm{P}$

\subsection{Isolhermal experiments}

\subsection{Isollinrmal smiterimg}

In this sectom the minimum temperature required to oblatn densities $245 \%$ " with the different invesligated compositons is sought. This temperature should preferably be below $12(1))^{\prime} \mathrm{C} 10$ obtann very fine-grained microstructures, stnce grain growlh in Y, Ce TZP accelerates above thos tempelature, as has been shown un Fig. 3. In Fig I0 the increase In relattue densily with time at 110105 and 1167 ' $\mathrm{C}$ is shown for three compositoons ZY5, ZY4C22 and ZYACeX At Ilos C densiticaluon proceeds slowly: after $15 \mathrm{~h} 95-96^{\circ}$ \% is reached for the Y, Ce-TZZPs and 42\% for $Z Y^{\prime}$. At $1167^{\prime \prime} \mathrm{C}$ densitication is much faster and denstles near $45 \%$ are oblanned after only

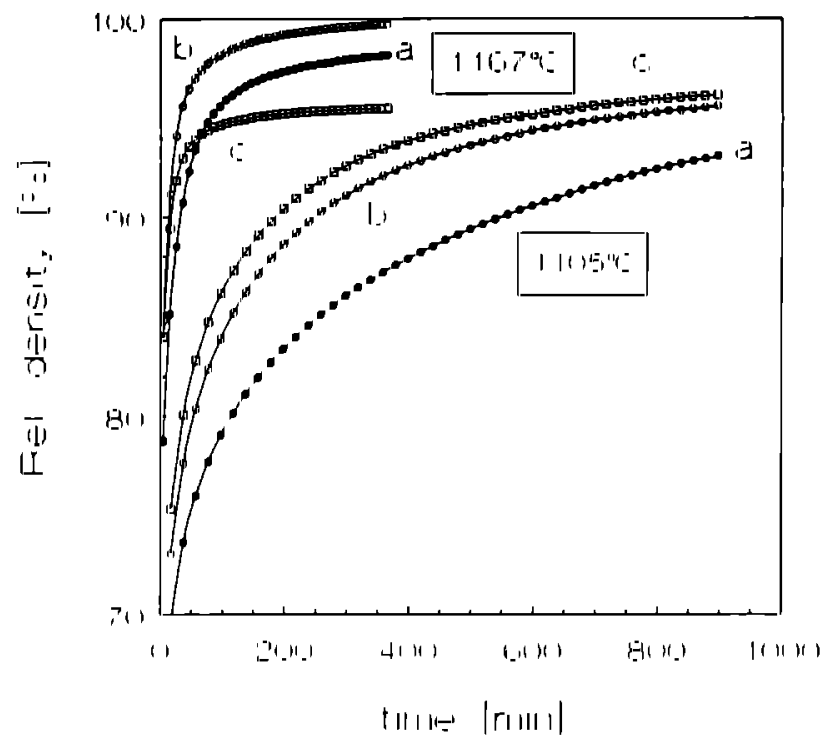

Fig. 10. Relallwe denslly as a luntilen al lame during frece

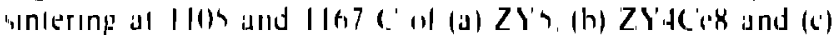

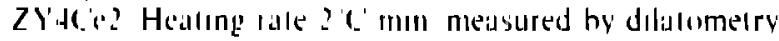

2110 mon lorr all three compositions Separate sinter mg experments perforned in a tube furnace alt $11001-11500$ contirmed the results obtained with the dilalomeler and showed very little diflerence in end densitles for the foul investigated ZYACer $11=2-8)$ composolions. Al 11010 ( $)$ the final density of ZY'S is generally lower than those of ZY4C'en, at 1150 Call densilles are quite similar. Sintermg experoments peilormed wath other powder batches, having the same chemcal composituon as stodod hele, show that the sontering results presented in Fig. 10 are reproducible. Gralln sizes alter isothermal somtermg are reported in Section 322.

Based on the authors' experience with diffetent halches of ZY 5, ZYtCere and also ZCel2, Il cun be concluded that the sontering hehaviour al such low

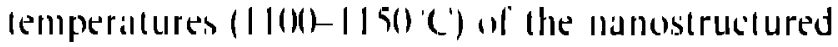
powders produced hy the chloride method is controlled predominantly by the degree of ag glomeration and 10 a much lesser extent by the composition, provided no exaggeraled grann growth oceurs, as lior instance in $\mathrm{ZCe}^{14}$

\subsubsection{Isor/hermal gram gromith}

By low-temperature sintering-als described in the previous sectonn-the authors have tried 10 limit gram gonwlh. The monmum temperatuse to reach \pm 9 \$" relative density has been lound equal to Iloor Cor Y, Ce-TZZP, the minmum attumable grain size heing, equal (o 1 ) 1 h $\mu$ m (reached alter 200 man al this temperaturel lor these materials. Figure II shows this microstructure for $\mathrm{ZY} 4 \mathrm{Ce} 2$

Graln sizes alter isothermal heal treatment at II 5()$-14(K)$ 'C are given in Tuble 2 for Z,Y $5, Z, Y 4 C e$, and ZCel2 All samples had densiles of $45-49 \%$ It can be seen that after 1150 " $\mathrm{C} / \mathrm{l}(\mathrm{h} \mathrm{h}$ all compositoons have an identical graln size $(1) \cdot 2 \mu \mathrm{m})$ At higher 


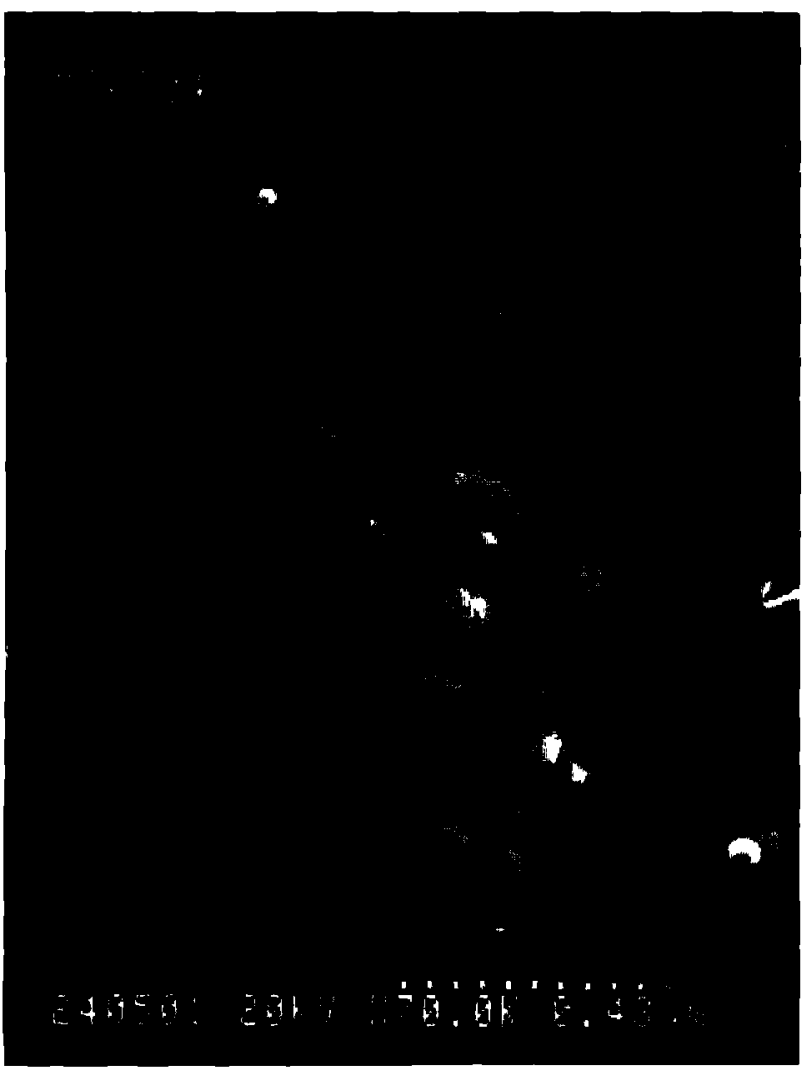

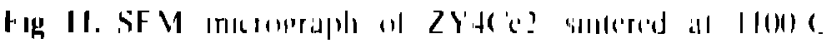

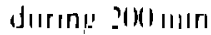

temperaltures. however. Ihe doflerences in gralm growwh rales become apprectible Al 14(0) C gralll

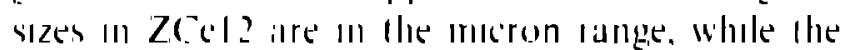

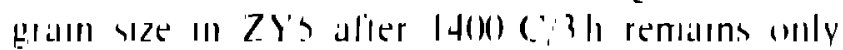

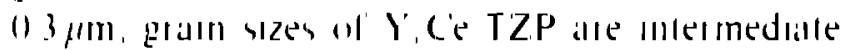

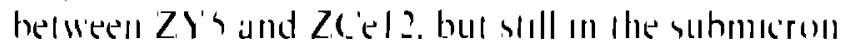

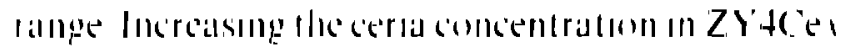
inllh $1=2-8$ ) does not allect graln growth withon

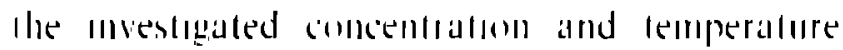
rallige

\subsection{Grain boundary segregalion}

It his been demonstrated al the previous sectoon thal graln giowthof Y' Ce.TZPal I $4(0)$ (C) is mlermediate berween I' TZP and Ce TZP, the largest gram sazes heing obselved lor ILCe TZP. At much lowel

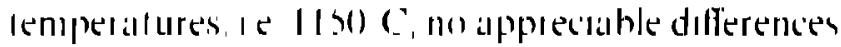
were lound. Therefore the segregatorn of vilrum and cerlum lo the glann houndaries hals been inalvised with XPS allet heal treatments in alr all

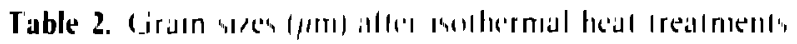

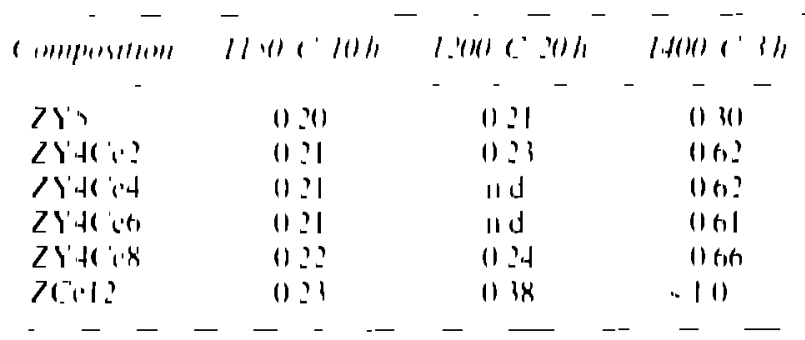

rid Noldrimimed

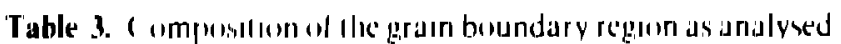
hy XPS

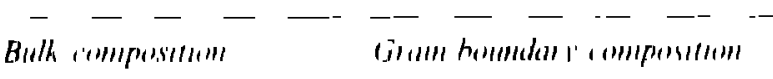

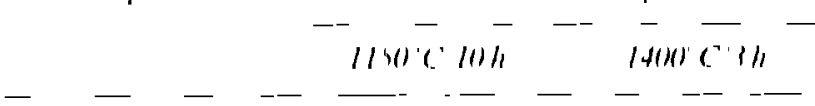

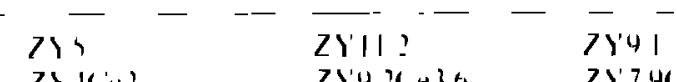

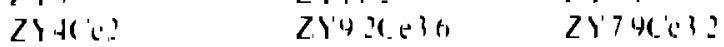

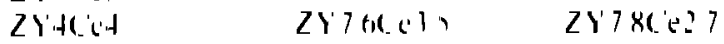

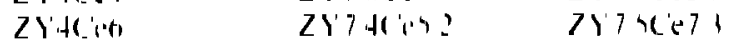

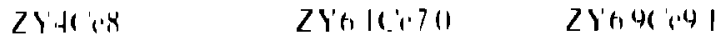

$1150)^{-1}(10 \mathrm{~h})$ and $\left.14(1)\right)^{\prime}(3 \mathrm{~h})$ The posisible presence of silcon at the gran boundares has also been cxammed

The composition of the grain boundary regions as determincd by XPS are given on Table 3 for $Z Y S$ and

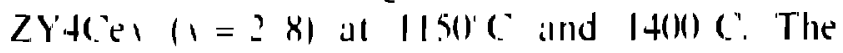
inlormallon depths in the XPS analysis are $5-6$ nm, for ZI. I'and (O) and $3 \mathrm{~mm}$ lin ('e In Y', Ce-TZZP very lille segregallan ol centum has been observed, whole vilum was enriched hy a factor al - I with respect lo lhe hulk compostlon al holh temperatures Table Balso shows that the yolrom enrichment ol the grain holladalles in ZY's, as sluded by XPS, is slighlilly

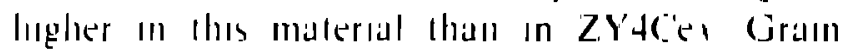
homlladric's In ZY's halle heell allalysed in greater delanl wilh XPS, SAM and TEM and the results ate lully dexished an Ret 34 The most important

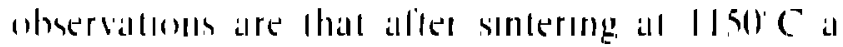

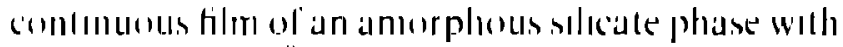

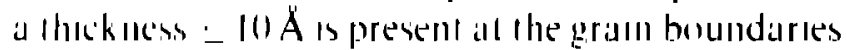
(TEM) and that the Y' Zr Iallo on the tirst I- 2 nom is as hogh as 1 3 (SAM) In Y', ('e.T'ZP no solicon could be detected wilh XPS

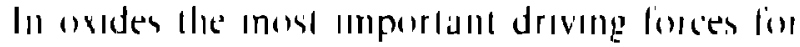
seglegallon ol solule calloms lo the liee stolaces or

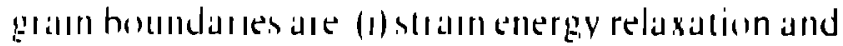

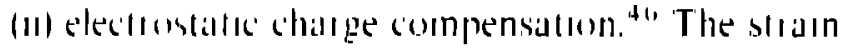
energy arises from the saze insomalch between the

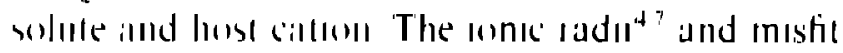
values : $\left(==\left(R_{\mathrm{A}}-R_{\mathrm{B}}\right) R_{\mathrm{B}}\right.$, where $R_{\mathrm{A}}$ is the comm radius of the solute callont and $R_{B}$ the loms radius ol $Z r^{+t}$ foll he calloms present on the zirconta cerames studed hecc alc given III Table' 4 As can be seen in this lahle. Ihe mistil mcicases an the order (.ett,

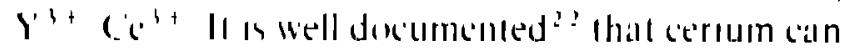

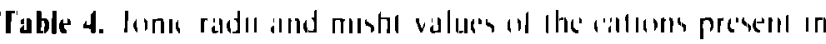

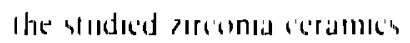

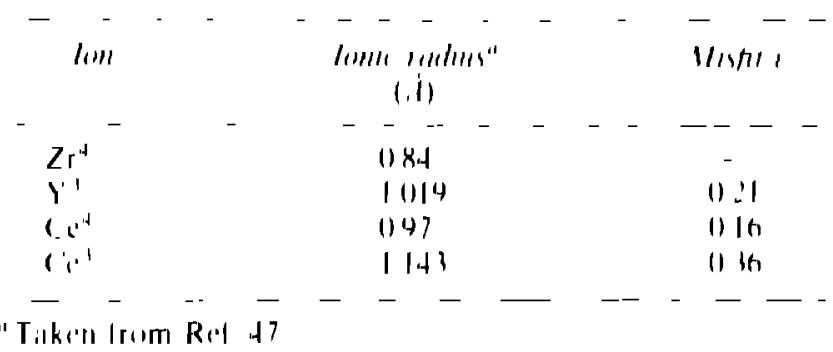


'Table 5. Binding energies (BE) al' the photocleciron lines in the Co $3 d$ reglonn dx when cernum is in a moxed oxidaloun slate

\begin{tabular}{|c|c|c|c|}
\hline $\operatorname{lin}$ & $\begin{array}{c}B E \text { ld } \\
(|+|)\end{array}$ & $\begin{array}{c}B E W_{3} \\
\left.\left(C^{\prime}\right)^{\prime}\right)\end{array}$ & $R+' m+m k$ \\
\hline \multirow{3}{*}{$C^{\prime} e^{4}$} & $x K: 1$ & P(II) $\mathrm{h}$ & Marır lırles \\
\hline & $8 \times 84$ & 41171 & Silallites \\
\hline & 8481 & 4169 & Sulellites \\
\hline \multirow{2}{*}{ Cét } & $8 \times 114$ & 8447 & Mann lines \\
\hline & $8 \times 4.3$ & $\varphi(1)\}$ & Sulcillates \\
\hline
\end{tabular}

be in the tovalent state aliter sintering in air all elevated lemperatures A large driving force for segregalion is expected for trivalent cerrum because of the considerable size mismalch (Table 4) and the charge difference between $\mathrm{Ce}^{b+}$ and $\mathrm{Zr}^{4+}$ Thereliore, the oxidation state of cerrum in YCe TZP has heen studied by means of XPS. Fur this purpuse, the Ce 3 d spectra of $Z Y 4 C e 2$ and $Z Y 4 C$ eX halve been recorded after sontering in alr all 11 h(1) and $14(0) \mathrm{C}$

The binding energles (BEs) of the main and

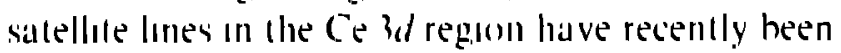
reporled for $\mathrm{CeO}_{2}$ and $(\mathrm{C}, \mathrm{O})$, by Paparazzo $\mathrm{C}^{\prime} \mathrm{a} \mathrm{l}^{\text {th }}$ and are given in Table. 5. The presence of I wo shake up sulellite parrs of the Ce $3 \mathrm{~d}$ doublet lon $\mathrm{Ce}^{+t}$ and one shake-up satellate pair lou ("e" ${ }^{1+}$ with intensilles approaching those of the main lones makes the quantitative analysis of the Iractoon of trivalent cerrum quile complicated Nevertheless, an altempt has been made to determme thas fractoun by deconvolution of the ce.3d region, yielding the

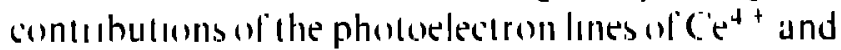
$\mathrm{Ce}^{1+}$ lo the observed intensity profile.

Only in the case of $\mathrm{ZY} 4 \mathrm{Ce} 8$ was the signal-10 noise ralos sulficient (1) allow deconvolution of the Ce 3 d regron. Deconvolution has been perlormed with the soltware package supplied by K ratos to the K'ratos XSAM $-8(1)$ apparatus. The lollowing procedure has been used: (1) Gaussian line profiles were assumed. (11) the binding energles of 'Table st were used as starling values and a BE interval of I eV, centred around the BEs of Tahle 5 lor each line, was allowed during, minımizalloon, (III) the upper limil of the liull width at half maximum (FWHM) was set at teV for each line and (Iv) the FWHM al each line belonging to elther $\mathrm{Ce}^{++}$and $\mathrm{Ce}^{3+}$ should have the same value.

Deconvolution of the Ce $3 d$ region performed in this way demonstrated that the fraction of Irivalent cerium at the gram boundaries of YCe.TZP equals approximately $50-55 \%$ independent of temperalure Figure 12 shows the Ce $3 d$ spectrum of the liracture surface of $Z Y 4 C \mathrm{C} 8$ afler deconvolution. the various photoelectron peaks of both cerium species are indicated.

Since (I) no eflect of increasing cerra concentration (n) graın growth in ZY4Cer has heen ubserved and (ii) the grain boundaries are not enriched in cerium, but show identical enrichment in yltrium, It is concluded that the migration of the segregation laver of yltrium along with the moving grain boundary is the rale-limitıng step durıng gram growlh in Y,Ce-TZP. This point is further elahorated in Section 4

\section{Discussion}

\subsection{Sintering and concurrent grain growth}

Durıng heilting with 2 Cimin final densities . $.95 \%$ are ohtalned at 12000 with all investigated composilons. Below this temperature densification and grain growth are occurring simultaneously Two regimes can be distingulshed here (Section 3.1) a LT regume al temperatures below $y()(x)-1(0)()^{\prime} \mathrm{C}^{\circ}$ and a $\mathrm{HT}$ regame between $9(0)-1000)$ and $12(0))^{\prime} \mathrm{C}$. In the LT regame only a very lomiled gram growth and densitication is observed. but important structural changes are nevertheless lak ing place. The neck area increases strongly from I2"' on the green compact to

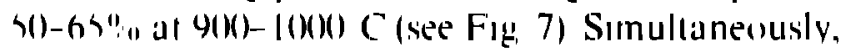
pore coursening is laking, place Since the neck area increases strongly with only little densification surface diffusion is the dominant malss transport mechanism levaporallon-condensalton processes are very unlikely at these low temperatures). In a (wo) sphere model no densification can occur with surlace diflusion. Lange, 414 however, proposed recently that in real powder compacts some densitic

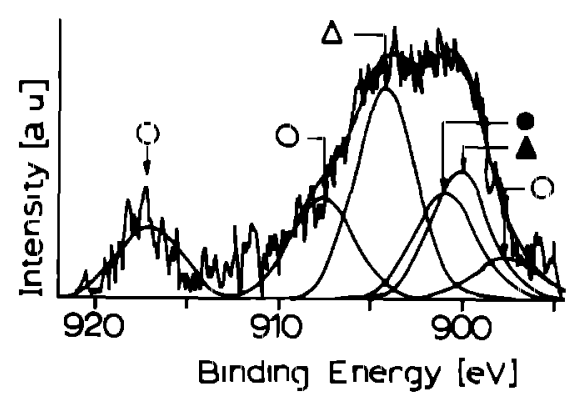

(d)

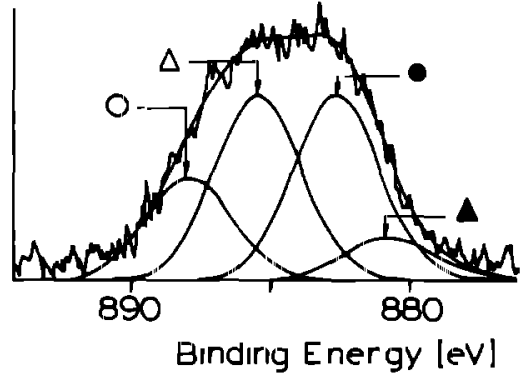

(b)

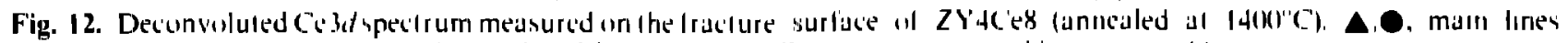

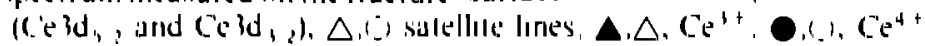


atlon miay occur if diflusion distances are short, als in the nanostructured materials studied here. Below Io(o)" $\mathrm{C}$ a grain growth exponent $\|=3-4$ best fitted the data for all investigated composilouns Greskovich \& Laly ${ }^{\text {th }}$ reported similar graın growlh kimetic's in very porous alumona compacts at 1470 (.) They Indeated that il surlace diffusmon predomi nales and gralln houndaly migratoon is rapid compiated to neck growllt, a graln growll law wilh $"=3$ is ubeved Such a grilll growith mechammsn could well he operalang an the L.T reglme on the TZZPs

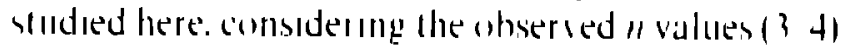
and the liac that surliate diflusion was fintund lo be the dommant malss transport mechantusm

In the HT regume ( I000)- I 200) (C) graingrowth and densticallon acceleralte clearly (see Figs 1 and?) Gralln growilh III Y TZP is slgghly liaster than in Y'C TZP, hut dhas must he correlated with the liaster densticaton of Y' TZP leadme to a langer

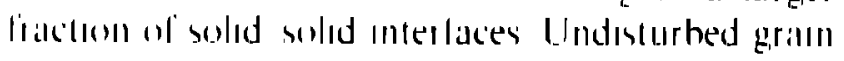

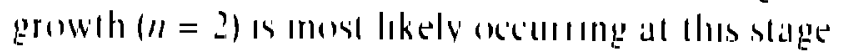
comblering the relatively lon temperaltures

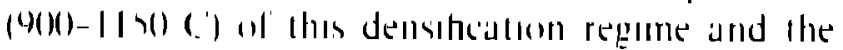

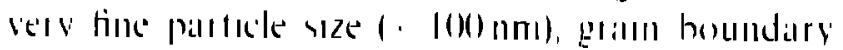
deflusmoln is comsidered an be the domoriant mass Iranspond mechanosm Analviss of the smtering

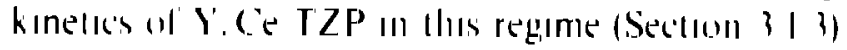
showed thall the tame-dependence ol relative shrmk

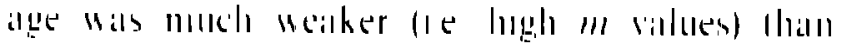
expected an the hasss ol gralln houndary fand volume) doffustum lwo sphere models lsee Sectom 3 I 3. A simalar lame dependence as observed here his heen reponted by Douran et al " "who perlormed isothermal sintermg experments al 9hol-lobse. with E.-TZ.P This weak lome dependence is most likely due to teorganizatom on the particle stacking. induced hy locial particle coordinatom floctuatoms as explained by Vermgal "Thos leads lo opemng of langer pores and morocracks ofl the amplatude ol the Hoctlattroms os larger lhall a crotcal value), which alre onlv slon/s temoved during proggessive sintermg

It in interestmg to mole that the microstructure development of hanosircictured tolantal durme non

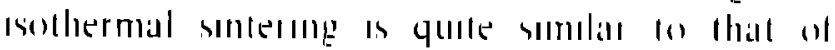
flocollia reponted here Halon ot al"' also ohserved Ino regimes III Tio: helow g(o) (C gralln growith proceeds vers slowly and suldace diffusmors is the dommant mass transponl mechanom, ahove $y(x)$ (. grang growth is verv liast

\subsection{Grain growth in the dense state, relation with solute drag}

As alreadv illusliated, gralln growth durmg sintermg, is influenced stgmiticantly by the densificatom process ilsell. Differences an grain houndary mo. bilites with compostlon ate thus easter to recogmize in mon densifving systems as described in Sectom
3.22 It has heen lound that the differences in grain growth of Y'TZP, Ce TZZP and Y,Ce.TZP are insignticant al 1150 (C) and only become important

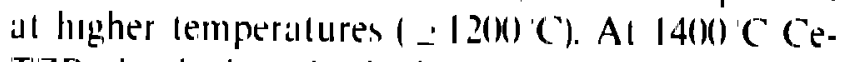
T'ZP clearly has the highest grann boundary mohility, Y' 'TZP the lowest and Y'. Ce.T'ZP is mermediale between these (wo)

Winnuhst a' al "were the tirst lo suggest that gram

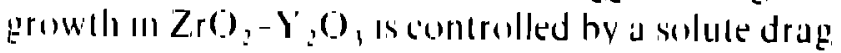
mechanssm In Secdonl 3.3 it has been shown that hoth III Y'TZP and Y'C'C.T'Z.P It is vittrum that segregales 10 the geraln boundaries with the hoghest segregallonl levels abserved In Y TZP This is in gered agleement with the XPS analysis of Theums sen it al $\therefore$ " ol' segregallon to the free surfices of $Y$ ' TZP and I'. (e'TZP ll has lurthermore heen ubserved llat the level of vilrom segregatlon was

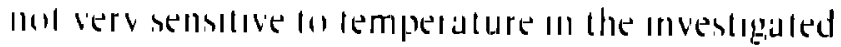

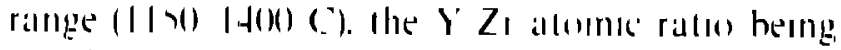
equal to - 11 I (enrichoneml lackor - 2) al the gram houndalles als measured ho XPS SAM meisure

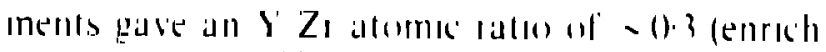

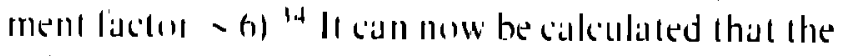

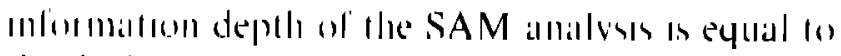
lhe thickness of the segregalion laver, whole the XPS allialsiss hats all molormation depth that extends into lle bulk al' the gralms with mumulaal chernicial

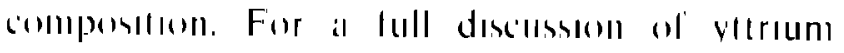
segregidson all Y' TZP the teader is refersed in Rel

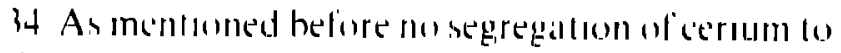

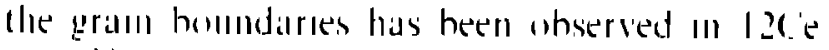
TZP: $: 1$

In sectom 3 i a has been demomstrated that

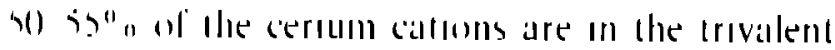
stale all the glam boundarles of YCe TZP aller

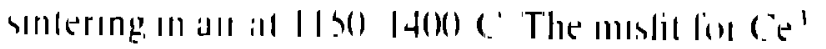
in riconla is quile high (see Table 4). hut mo semiticinl segegatom of cellum has been ohserved

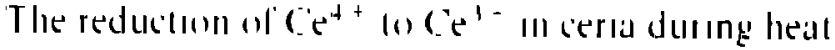
trealments in alar tiakes place al temperalures helow If(0) \& "anly il traces of silica are present" Therefore, It is anticipilted that cerlum is only movalent al the gran boundalles of YC' TZP where slacal is piexelll he il in concentrations below the

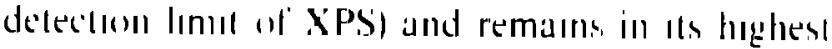
oxidallon statc an the graln interom This is supported by the impedance allalysis ol' Y' 'T"ZP and Y'ce TZP (sontered in aur) perlinrmed hy Hernandez it al, "ht who observed that the bulk conductuvity of Y TZP did not increase when codoping with cerla Such an inciease of the hulk conductovily should have heen observed il ceroum was trivalent in the grain Intelor of an ionc conductor lake Y'TZP, smce this would have led co an inciease of the oxygen valciancy concentrallon alcoordang (o)

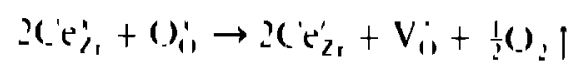


Although differencess in segregalion of the stabi lizers are quile signiticant comparıng, Y-TZZ, Y, CeTZP and Ce.TZP, dafierences in grain growih only appear clearly al 140()$^{\prime}\left(C^{2}\right.$. Examination of the microstructures alter $11,0(\mathrm{C} / 10 \mathrm{~h}$, showed no evidence lor pormang, of the grain boundarles by residual pores II is therefore propossed that at IIsol $C$, being a very low temperature for grain growth in dense TZP, grain boundary velocilles ale sol low, that the segregation layer exerts no drigg on the moving boundary At hagher temperalures the grain boundary velocily increases and the segregalted layer starts exerting a dag on the boundally This daag is maximum in Y'TZP. ahsent in ('e 'TZP and intermediate between these in two in Y'. Ce 'TZP. explanming the differences in grain growtla wbserved at hogher temperalures

\section{Conclusions}

(a) Nanustructured Y'-TZP and Y.Ce TZP.P puwders produced by the chloride-method cun be pressureless densitied al low tempera lures $\left(1100-1150(0) 10\right.$ densitles $=45^{\circ} \circ$ with alverage grain sazes o $11^{\circ} 015-1$ (1) $211 \% \mathrm{~mm}$

(b) During inon-msothermal sintering of these malterlals iwo regirnes are distinguished one below $9(0)-1000)(C$, in which the neck area increalses strongly with only little densitication and one al temperalutes from $9(x)-10(0)$ (1) 12006 . whete the largest parl ol demsitic allon ocsurs Al low lemperatures surface diffusion is the dominant malss transport mechanism Above 101010'C densitication occurs mosl lakely via grain boundary diffusion and is retarded by reorganizalion processes

(c) Gian growth durıng non isothermal sinter ing can be simularly divided inlo) (wo regimes. Below 9001-10001 C neck linmation via the surfice ditfusion is rate limitıng $(11=3)$, while above this temperature the neck ared has moreased $(0)$. 6) growth (11 =2) occurs for all investigated composilions

(d) Segregalton of yltrium to the gram hound. arles is observed al $1150-140010$ in hoth $Y$ TZP and Y, Ce-T'ZP, the highest segregation levels being ohserved for Y-TZP No signiti'all segregation ol' cerium has been found in Y, Ce TZP. In Y-TZP the enrichment liator equals $\pm h$ in the first $1-2 \mathrm{~nm}$ of the gram boundary regan as lound by SAM.

(e) Normal grain growth occurs al $11,50-12001 \mathrm{C}$ In dense TZP and very little diflerences with composiluon ate observed. Al higher lemper atures grain growth is controlled by a solute drag mechanısm This drag is highest for Y TZP, absent for 12Ce TZP and moderate for Y, Ce TZP. Increasing the cerla concentration at constant yttra content has no effect on grain growth and ytirla segreg. atton withon the investigated composition serles $(Z, Y 4 C$, , with $1=2-X)$.

\section{Acknowledgements}

Akzo Chemicals b.v is gratefully ack nowledged lor finuncial support of this investigation. René Olde Scholtenhuss is acknowledged lou performing part of the powder synthesis and sample preparation, Theo Leuwerink lor perlormıng physisorplonn and mercury penelratoon measurements, Joop Snoeyen. bos lor machınıng and polishıng, Jaap Boespsma for his assistunce with XRD measurements, Marc Smithers lior SEM wbservallons and Alherl van den Berg fior recording the XPS spectra.

\section{References}

I Siwall. $M V \&$ Rose $L \quad R$, Strenguh limulalions of

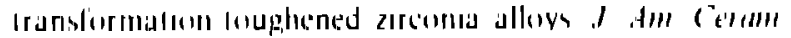
Siri, 6917)(1486) $411-18$

? (ircern D) J Hannınk, R H J \& Suaın, M V,

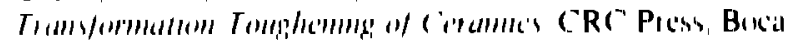
Ralonl Florida, 1484, pr. h4-84

I 'Trolkumb. K', Kuholla, Y' \& Tsukidale, T, Thermal and

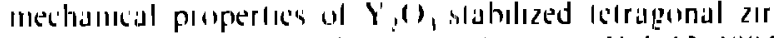

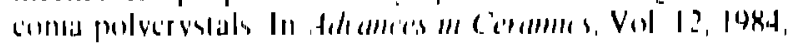
PP) $18:-411$

† Wang, I Ralmblurlh, W M \& Slevers R, The grain size dependerice al the mechantical propertices in TZP ceramis's

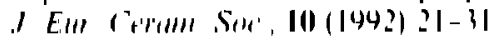

' Lunge, F F, Translormaloun loughened Zro, corrclalions helween graln size comlinal and composillan in the systern

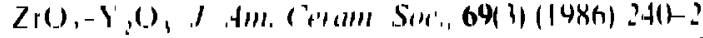

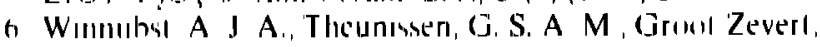
W F M \& Burggidal', A I. 'The smlering hehavour wh hote

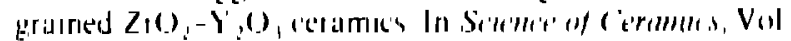
i.t 1487, W1 $1114-14$.

7 Nieh, T (i \& Wadsworlli, J , Dynamuc gerain growwh durng,

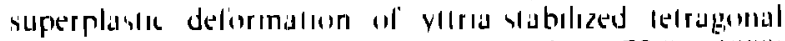

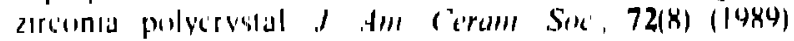
$1+464-72$

8 Nalue M \& Carry, C liran growlh in yllradoped

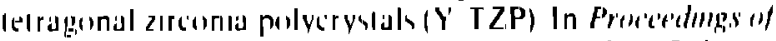

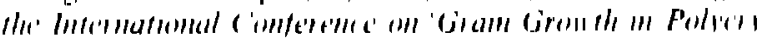

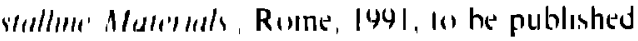

4 Theunisien G S A M Winnuhso, A J A \& Burgeriali, A. I. Sinlering, kinelice and microblluslure developmenl al

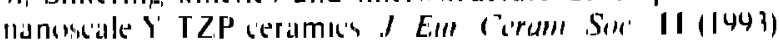
$314-24$

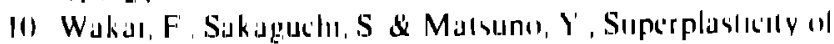

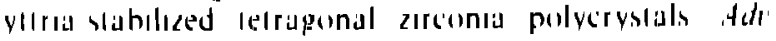

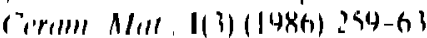

II Silo, 'T \& Slumida, M, Control al the lelragonal lo

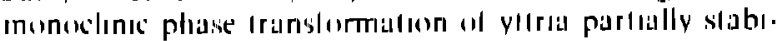

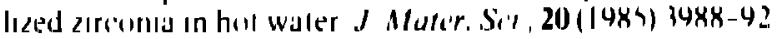

12 Wimrubii, A I A \& Burggrial, A I., The ageing behaviour

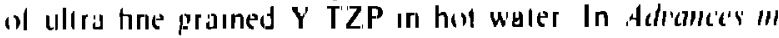




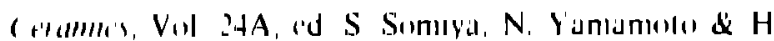
Hanilplda American ceramic Sociely. Westerville, (OH 1488 ip $319-47$

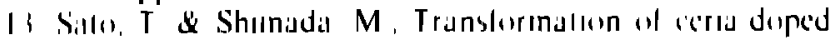

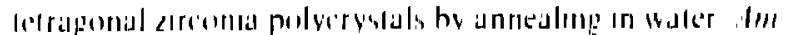
Cirimin Sirr Bull, of (1984) I Bk:-4

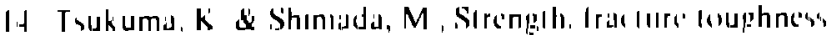

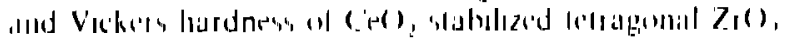

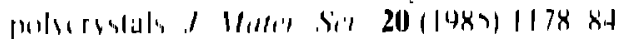

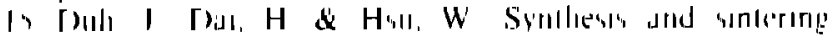

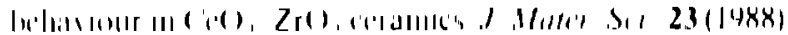
? 786,41

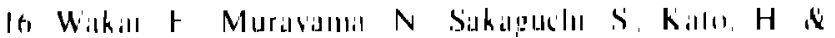

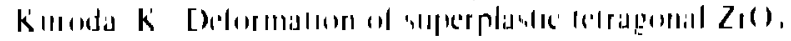

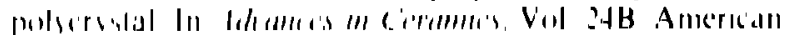

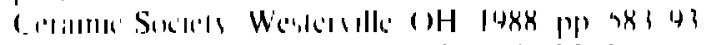

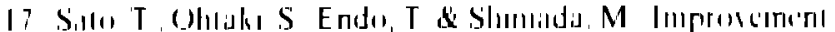

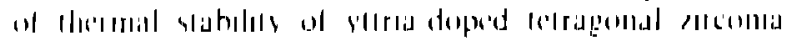

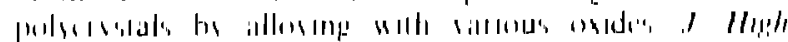

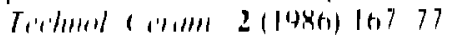

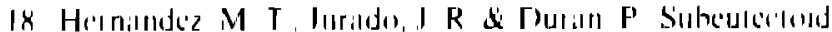

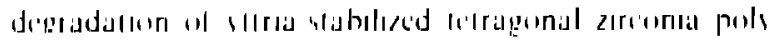

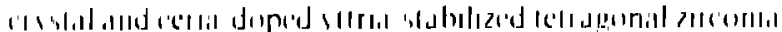

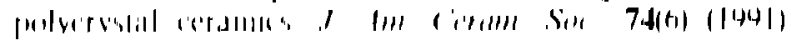
l? 2 , 8

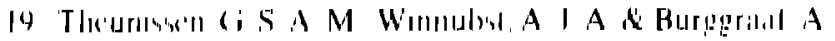

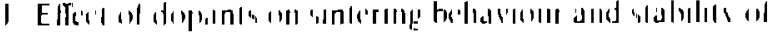

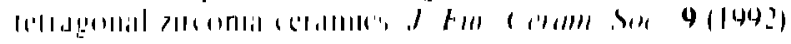
2il of

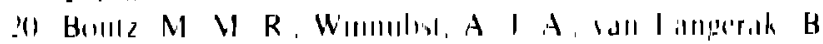

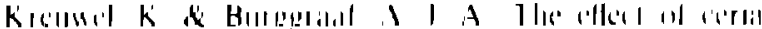

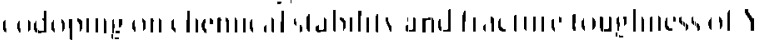
T가, I I/1/1', ל,

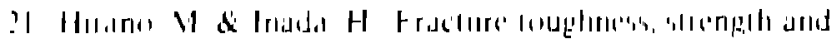

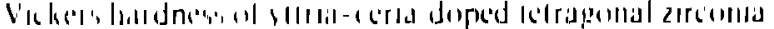

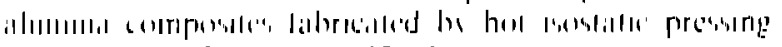

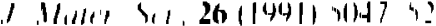

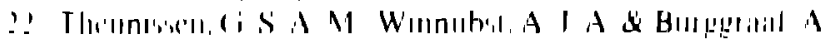

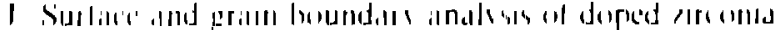

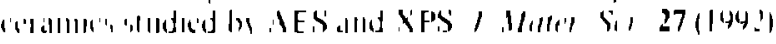
10107010

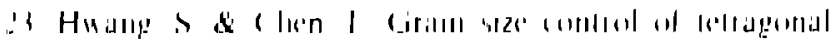

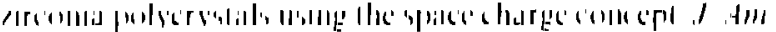

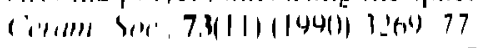

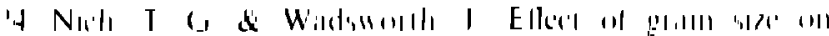

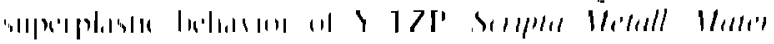
$2+(1) 01) 1+3+t$

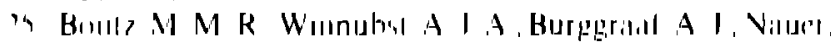

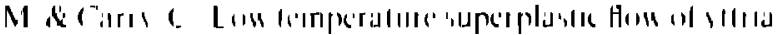

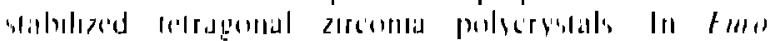
I '

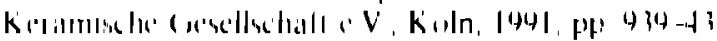

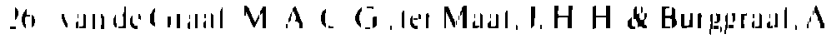

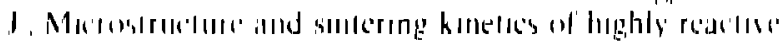

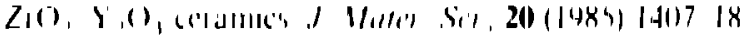

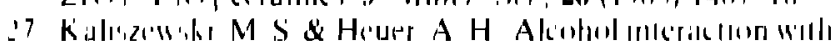

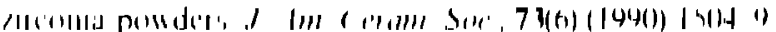

is Cirnol levill W F M , Wirmulow, A I A Theuris'sen (; $\rightarrow$ A V i Burgerad A I, Fowder preparallon alnd

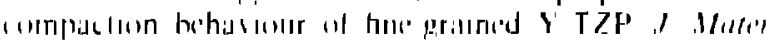
4, 25 (1991) i. 44 की

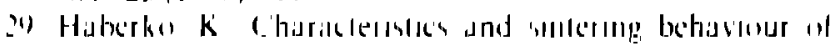

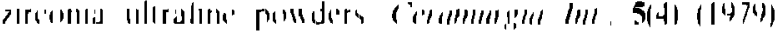
$1.4 \times \quad 4$

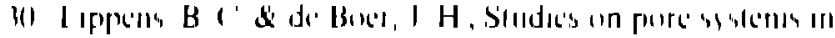

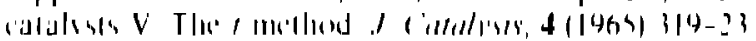

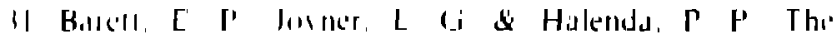

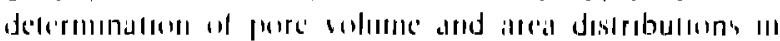

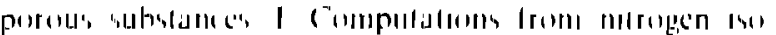

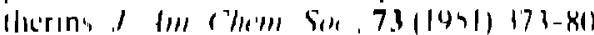

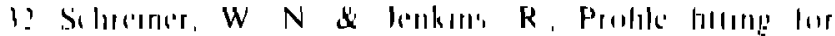

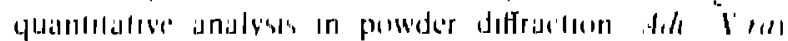
timal $2 \mathrm{~b}(1483$ i 141 ?
3 Morndelson, M I, Average gram size an polycrysalline

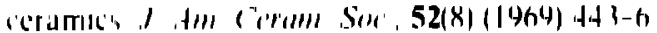

3.t Boulz. M M R, Chen, C'S Winnuhis, A I A \&

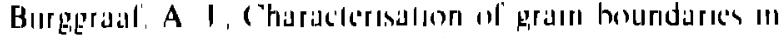

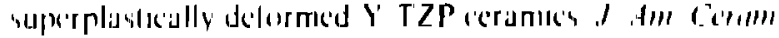
Sin

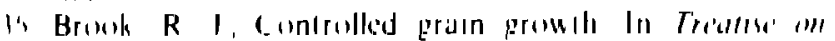

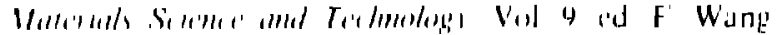

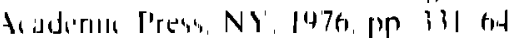

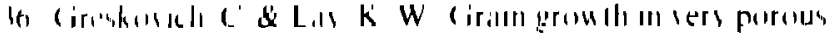

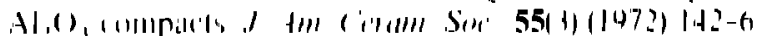

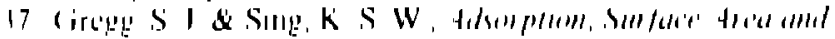

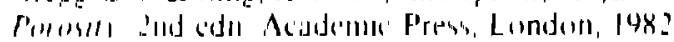

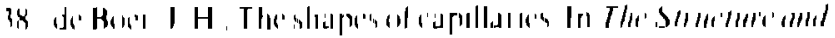

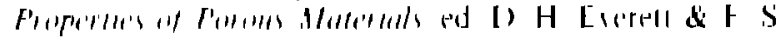

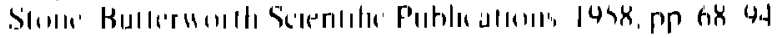

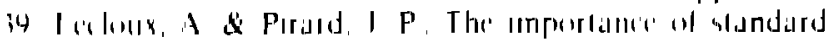

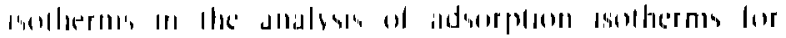

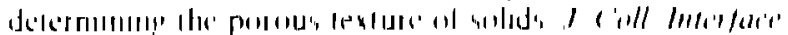

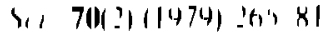

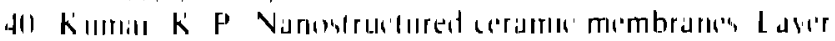

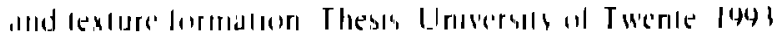

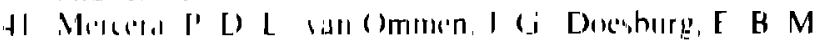

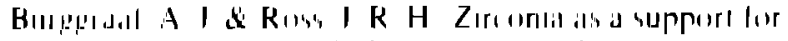

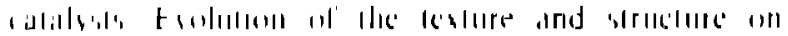

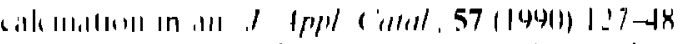

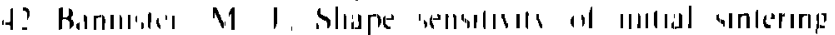

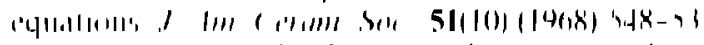

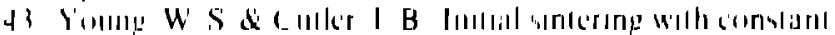

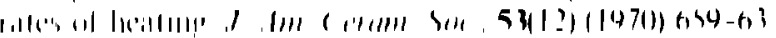

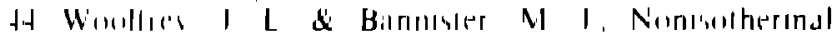

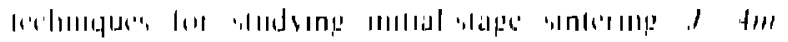

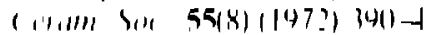

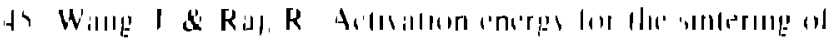

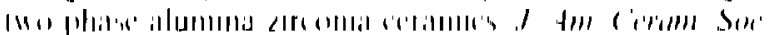

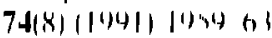

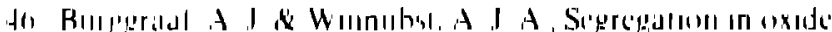

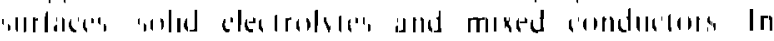

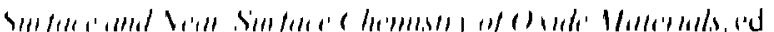

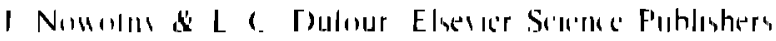

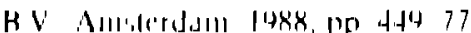

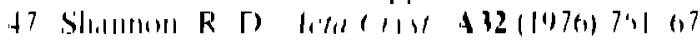

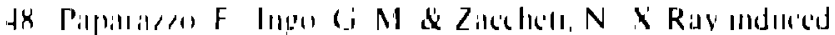

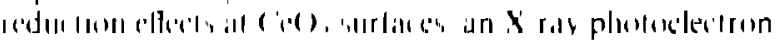

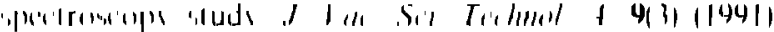
It Ih :

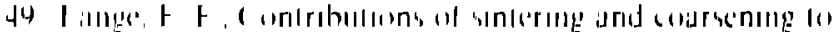

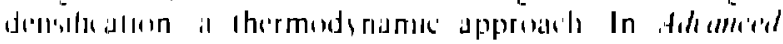

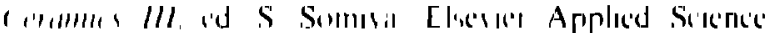
Loridull and Nin York, 1490), pp 77 70

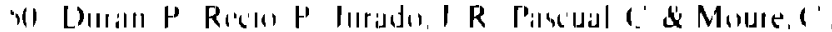

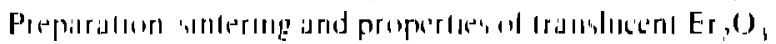

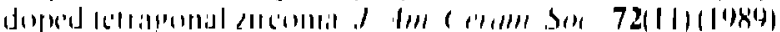
$\operatorname{lin} 8 \times 84$

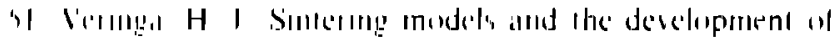

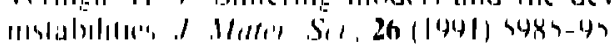

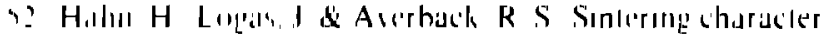
(⿻)丨

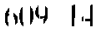

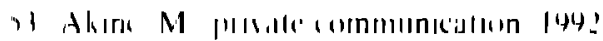

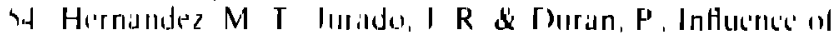

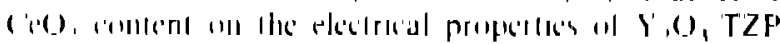

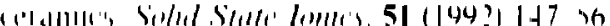

\section{Appendix}

A geller a grall growth equatlon will be derived here for the case of lieatung with a constant rale $\beta$ The termmology used and basic lornmulas are in ice. cordance with Ref 35. The central assumpleon for 
analysing grain growth kinetics is that the growth rate is directly proportunal to the average rate ${ }^{\prime}$ ol gralun houndary meration The average rate 1 can be written als a mobility $(M /$-fiorce $(F)$ product. The startang equation is therefore equal to

$$
\frac{d}{d l}-1=\Lambda I F
$$

The driving force for gram boundary meration is usually laken to he inversely proportonal to the graum size

$$
F=\frac{k}{[)}
$$

The varous parameters that characterize the rate limiting step are thus included all the mobility term.

The migration of the houndary can he controlled by (a) the boundary otself or (b) the megration of pores allached to lle boundary In the case ol boundary contool the mobility of the houndary $\left(M I_{1}\right)$ nusl be inserled in eyn (Al)

$$
I^{\prime}=M I_{\mathrm{l}} F
$$

In the case of pore control eyn (A l) maly be wollen as

$$
i=F\left(\frac{M I_{\mathrm{p}}}{N}\right)
$$

where $M I_{p}$ is the pore mobility and $N$ the number of pores allached lo the boundary.

To evaluate grain gow tow kinelics from $M_{\mathrm{p}}$ and eqn (At) lwo lurlher alssumptions are necessarv.

(1) the average pore size is related to the average grain size by $r-D$,

(2) the number of pores $N$ is inversely poupor. tandal to the square of gram soze $\left(N-1 / L^{2}\right)$.

In Tuble 3 of Ref 39 the expressions for the mobilaties are given for the various possible mech. anisins. Fiom this lable, the above mentioned alssunptons and eyns (A 3-(A4), it is clear that the lorce-mobilaty product can be wrillen as the quolient of a lanctoon of temperature gil $T)$ and one ol" gram size $/([0)$

$$
t^{\prime}=\frac{g(T)}{l([))}
$$

The functung g(T) can he written for each mechan IsIII I as

$$
g_{1}(T)=K_{i}\left(\frac{\tilde{D}_{1}}{T}\right)
$$

where $\tilde{D}_{1}$ is the chemical diffision coefficient for mass transport inechanism, The functuon $f(D)$ can be writlen as"

$$
f(D)=L)^{n-1}
$$

Inserting, eqn (AS) Into (AI) and integratıng gives:

$$
\int /(D) \mathrm{d} D=\int g,(T) \mathrm{d} t
$$

During healıng, with a constant ralte $\beta$ lemperature and lime are coupled by.

$$
T=T_{11}+\beta t
$$

where $T_{11}$ is the starting temperature (roum temperature ill the present measurements). Instead of integrating the right-hand side of (AX) in lime, as in the case ol constant temperalure, one now has to integrate in temperature

$$
\int_{I_{11}}^{g_{1}}(T) \mathrm{d} t=\int_{I_{11}}^{t} \frac{g_{1}(T)}{R} \mathrm{~d} T
$$

Inserting equ (b) and the relationship ${ }^{\bar{D}}=$ $D_{11} \exp (-Q / R T)$ inlo eqn (AIO) ylelds.

$\int_{\Gamma_{11}}^{T} \frac{R_{11}(T)}{\beta} \mathrm{d} T=\frac{K_{1}^{\prime} \bar{D}_{11}}{\beta} \int_{\Gamma_{11}}^{\Gamma}\left(\exp \left(-\frac{Q}{R T}\right) T\right) \mathrm{d} T(\mathrm{~A} \mid 1)$

The inlegral from $T=0$ ) $10 T=T_{1}$ ol the lunction $g_{1}(T)$ is vanishongly small and the integral from $T=7_{11}$ (1) $T=T$ in eqn (All) can therefore be replaced by the integral from $T=0$ (1) $T=T$ The integral in eqn (A II) can then be solved andytically, but this leads an the lollowing inconventent poly momial expression

$$
\begin{aligned}
& \int_{0}^{T}\left(\exp \left(-\frac{Q}{R T}\right) T\right) d T \\
& =\ln (T)-\sum_{k=1}^{\infty}\left\{\frac{1}{k k !}\left(-\frac{Q}{R T}\right)^{n}\right\}
\end{aligned}
$$

The terms with $k \cdot 1$ in eqn (AI2) cunnot be neglected for realistic values of the activation energy () (order-ol'-magnitude 1()$^{\prime} \mathrm{kJ} /$ mol) and the investl gated temperatute range (up to $1423 \mathrm{~K}$ ). The solution of integral (AII) can, however, be well approximaled by:

$$
\int_{11}^{l}\left(\exp \left(-\frac{Q}{R} T\right) T\right) \mathrm{d} T=\frac{R T}{Q} \exp \left(-\frac{Q}{R T}\right)
$$

The validity of this approximalson can easily be recognized by differentiation of the right-hand side of eqn $(\mathrm{A} \mid 3)$, remembering that $R / Q$.. I. The validily has also been checked by numerically integrating eqn $(A \mid l)$ and comparing the oulcome with that of ecin (A I 3)

'The lell-hand side of eyn ( $(x)$ remains unchanged wrt the isothermal case and must he integrated from $\left[D_{11}(1)[\right.$. The final equatoon to analyse grain growth kinetics during healing, with a constant rate $\beta$ is therefore equal to.

$$
D^{\prime \prime}-L_{01}^{n}=\frac{K_{1} R T}{\beta Q} \exp \left(-\frac{Q}{R T}\right)
$$

where $K^{\prime}$ is a constant, $R T$ has its usual meaning and $G$ is the apparent activalion energy 